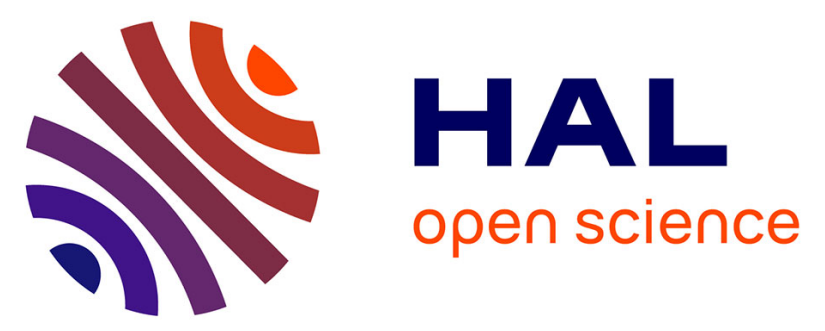

\title{
Timing and duration of meteoric water infiltration in the Quiberon detachment zone (Armorican Massif, Variscan belt, France)
}

Camille Dusséaux, Aude Gébelin, Philippe Boulvais, Gilles Ruffet, Marc Poujol, Nathan Cogné, Yannick Branquet, Catherine Mottram, Fabrice Barou, Andreas Mulch

\section{To cite this version:}

Camille Dusséaux, Aude Gébelin, Philippe Boulvais, Gilles Ruffet, Marc Poujol, et al.. Timing and duration of meteoric water infiltration in the Quiberon detachment zone (Armorican Massif, Variscan belt, France). Journal of Structural Geology, 2022, 156, pp.104546. 10.1016/j.jsg.2022.104546 . insu03576380

\section{HAL Id: insu-03576380 \\ https://hal-insu.archives-ouvertes.fr/insu-03576380}

Submitted on 16 Feb 2022

HAL is a multi-disciplinary open access archive for the deposit and dissemination of scientific research documents, whether they are published or not. The documents may come from teaching and research institutions in France or abroad, or from public or private research centers.
L'archive ouverte pluridisciplinaire HAL, est destinée au dépôt et à la diffusion de documents scientifiques de niveau recherche, publiés ou non, émanant des établissements d'enseignement et de recherche français ou étrangers, des laboratoires publics ou privés. 


\section{Journal Pre-proof}

Timing and duration of meteoric water infiltration in the Quiberon detachment zone (Armorican Massif, Variscan belt, France)

Camille Dusséaux, Aude Gébelin, Philippe Boulvais, Gilles Ruffet, Marc Poujol, Nathan Cogné, Yannick Branquet, Catherine Mottram, Fabrice Barou, Andreas Mulch

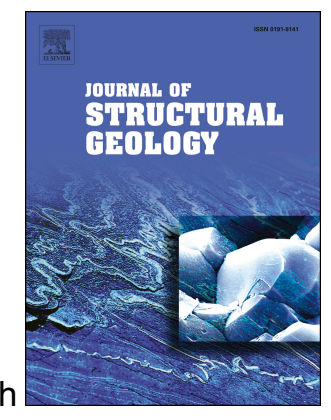

PII: S0191-8141(22)00038-4

DOI: https://doi.org/10.1016/j.jsg.2022.104546

Reference: $\quad$ SG 104546

To appear in: Journal of Structural Geology

Received Date: 12 June 2021

Revised Date: 6 February 2022

Accepted Date: 7 February 2022

Please cite this article as: Dusséaux, C., Gébelin, A., Boulvais, P., Ruffet, G., Poujol, M., Cogné, N., Branquet, Y., Mottram, C., Barou, F., Mulch, A., Timing and duration of meteoric water infiltration in the Quiberon detachment zone (Armorican Massif, Variscan belt, France), Journal of Structural Geology (2022), doi: https://doi.org/10.1016/j.jsg.2022.104546.

This is a PDF file of an article that has undergone enhancements after acceptance, such as the addition of a cover page and metadata, and formatting for readability, but it is not yet the definitive version of record. This version will undergo additional copyediting, typesetting and review before it is published in its final form, but we are providing this version to give early visibility of the article. Please note that, during the production process, errors may be discovered which could affect the content, and all legal disclaimers that apply to the journal pertain.

(C) 2022 Published by Elsevier Ltd. 


\section{Timing and duration of meteoric water infiltration in the Quiberon detachment zone (Armorican Massif, Variscan belt, France)}

Camille Dusséaux, Aude Gébelin, Philippe Boulvais, Gilles Ruffet, Marc Poujol, Nathan Cogné, Yannick Branquet, Catherine Mottram, Fabrice Barou, Andreas Mulch

\section{Credit Author Statement}

Camille Dusséaux: Conceptualization, Investigation, Sampling, Data Curation, Writing - Original Draft, Visualization

Aude Gébelin: Conceptualization, Sampling, Investigation, Validation, Writing - Original Draft, Supervision, Project administration

Philippe Boulvais: Conceptualization, Sampling, Writing - Review \& Editing, Supervision

Gilles Ruffet: ${ }^{40} \mathrm{Ar} /{ }^{39} \mathrm{Ar}$ geochronology - investigation, formal analysis, visualisation, writing Marc Poujol: Sampling, U-Pb geochronology - investigation, formal analysis, visualisation, writing Nathan Cogné: U-Pb geochronology - investigation, formal analysis, visualisation, writing Yannick Branquet: Investigation, Writing - reviewing and editing

Catherine Mottram: Methodology, Investigation, Formal analysis, Writing - reviewing and editing, Supervision

Fabrice Barou: EBSD

Andreas Mulch: Resources, Writing - Review \& Editing, Supervision 
3 Camille Dusséaux ${ }^{1,2 *}$, Aude Gébelin ${ }^{1,3}$, Philippe Boulvais ${ }^{4}$, Gilles Ruffet ${ }^{4}$, Marc Poujol ${ }^{4}$, 4 Nathan Cogné ${ }^{4}$, Yannick Branquet ${ }^{4,5}$, Catherine Mottram ${ }^{6}$, Fabrice Barou ${ }^{7}$, Andreas 5 Mulch $^{8,9}$

$6 \quad{ }^{1}$ SoGEES, University of Plymouth, PL48AA Plymouth, UK

7 2Université Grenoble Alpes, ISTerre, F-38058 Grenoble, France

$8 \quad{ }^{3}$ CEREGE, Aix-en-Provence, France

$9{ }^{4}$ Univ Rennes, CNRS, Géosciences Rennes - UMR 6118, F-35000 Rennes, France

10 5ISTO, Université d'Orléans, CNRS, BRGM, France

$11{ }^{6}$ SEGG, University of Portsmouth, PO1 3QL Portsmouth, UK

$12{ }^{7}$ Géosciences Montpellier, CNRS, Université de Montpellier, Université des Antilles, France

$13{ }^{8}$ Senckenberg Biodiversity and Climate Research Centre (SBiK-F), Frankfurt, Germany

$14{ }^{9}$ Institute of Geosciences, Goethe University Frankfurt, 60438 Frankfurt, Germany

15 Corresponding author: Camille Dusséaux (ca.dusseaux@gmail.com)

\section{Key Points}

- $\delta \mathrm{D}$ values of synkinematic hydrous minerals document the presence of 300 Ma-old meteoric fluids in a key Variscan detachment zone.

- Meteoric fluid-rock interactions occurred during high-temperature deformation $\left(>500^{\circ} \mathrm{C}\right)$ in the Quiberon detachment footwall.

- Coeval detachment activity, leucogranite emplacement and migmatization allowed the hydrothermal system to be maintained for $\sim 17$ Myr.

\section{Keywords}

Variscan; detachment; shear zone; hydrous silicates; hydrogen isotope; ${ }^{40} \mathrm{Ar} /{ }^{39} \mathrm{Ar}$; U(-Th)/Pb;

\section{Abstract}

Assessing the geochemical signature and the role of fluids in a key Variscan detachment zone demonstrates the link between crustal deformation, thermo-mechanical events and Variscan mineralization. We document meteoric fluid infiltration into the ductile segment of the LateCarboniferous Quiberon detachment zone (QDZ), when synkinematic muscovite and tourmaline crystallized and equilibrated with deuterium-depleted surface-derived fluids during high-temperature deformation. Titanium-in-muscovite thermometry supported by microstructures indicate that syntectonic isotope exchange between fluids and hydrous minerals occurred above $500{ }^{\circ} \mathrm{C} .{ }^{40} \mathrm{Ar} /{ }^{39} \mathrm{Ar}$ muscovite data $(\sim 319$ to $\sim 303 \mathrm{Ma})$ and $\mathrm{U}(-\mathrm{Th}) / \mathrm{Pb}$ geochronology on zircon, monazite and apatite ( 318 to $\sim 305 \mathrm{Ma})$ from syntectonic leucogranites together with microstructural and geochemical (U and REE contents) data 
role in leaching uranium at $\sim 305 \mathrm{Ma}$. U-Th/Pb data ( 330 to $\sim 290 \mathrm{Ma}$ ) from migmatites located below the QDZ strengthen the idea that meteoric fluid infiltration, detachment activity, syntectonic leucogranite emplacement and migmatization were coeval and allowed the development of a sustained hydrothermal system.

\section{Plain Language Summary}

We document the presence of 300-million-year-old rainwater in a normal fault that was in the internal zones of an eroded mountain range called the Variscan Belt, now outcropping at the surface in Brittany (France). Water-bearing minerals preserved the hydrogen isotope composition of the water that penetrated the fault zone at depth. The same minerals can be dated based on the radioactive decay of Argon. Combined with other dating methods applied to various minerals, we conclude that the rainwater infiltrated the fault zone 320 to 300 million years ago. This study allows a better insight of how fluids circulate in the Earth's crust, which is critical for our understanding of mineralization processes that form ore deposits.

\section{Introduction}

Extensional shear zones play a major role during lithospheric extension as they control mass transport through lateral and vertical displacements in mid to lower levels of the continental crust (e.g. Teyssier \& Whitney, 2002; Tirel et al., 2008; Whitney et al., 2013). The zones of planar weakness that separate the relatively cool upper crust from the hotter middle-lower crust may act as fluid conduits and, therefore, represent sites of strong fluid-rock interaction where meteoric, metamorphic and magmatic fluids interact (e.g. Dusséaux et al., 2019; Famin et al., 2004; Gébelin et al., 2011, 2015, 2017; Gottardi et al., 2011, 2018; Methner et al., 2015; Morrison \& Anderson, 1998; Nesbitt \& Muehlenbachs, 1995). Assessing the source of fluids in such hydrothermal systems has a range of applications including constraining the conditions for mineralization and ore deposition (Ballouard et al., 2017, 2018a; Beaudoin et al., 1991; Boiron et al., 2003) or paleoaltimetry reconstructions if surface-derived (meteoric) fluids are present (e.g. Dusséaux et al., 2021; Gébelin et al., 2012, 2013; Grambling et al., 2022; Mulch et al., 2004).

Based on the low hydrogen $(\delta \mathrm{D})$ and oxygen $\left(\delta^{18} \mathrm{O}\right)$ isotope values of synkinematic hydrous

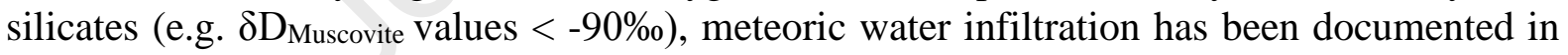
the footwall of detachment zones, e.g. in the North American Cordillera (e.g. Gébelin et al., 2011, 2015; Mulch et al., 2004; Person et al., 2007), in the Himalayas (e.g. Gébelin et al., 2017, 2013), and in the Variscan belt of Western Europe (e.g. Ballouard et al., 2018a, 2017, 2015; Dusséaux et al., 2021, 2019). Some of these studies (e.g. Dusséaux et al., 2019, 2021; Gébelin et al., 2012, 2013) highlight three main conditions essential for the downward infiltration of meteoric fluids: (1) the development of brittle normal faults and associated fracture networks in the upper crust that facilitate permeability of the crust in the brittle domain, (2) a high geothermal gradient with advection of partially molten material in the footwall that provides heat to support an active convection system, and (3) the presence of a hydraulic head provided by topography.

In this study, we focus on the Quiberon detachment shear zone (QDZ; Figure 1; Southern domain, Armorican Massif, France), an extensional shear zone with excellent exposures, that was active during the Late Carboniferous and developed as a result of late-orogenic extension (e.g. Gapais et al., 2015, 1993). The QDZ represents an excellent target to look at fluid-rockdeformation interactions and understand how, why and when fluids circulated in the crust during the Late Carboniferous because: (1) hydrogen isotope ratios $(\delta \mathrm{D})$ of hydrous minerals indicate that meteoric fluids infiltrated the mylonitic footwall of the QDZ (Dusséaux et al., 
2019), (2) the structural, metamorphic, and geochronological record of the region is relatively well established (e.g. Gapais et al., 2015, 1993; Turrillot, 2010; Turrillot et al., 2011); (3) brittle normal faults have been identified in the hanging wall of the QDZ (Figure 2A; Ballouard et al., 2015); (4) the QDZ is considered to have played a major role in the exhumation of high-grade metamorphic rocks (Brown \& Dallmeyer, 1996; Gapais et al., 2015), and (5) the region was characterized by a high geothermal gradient in part generated by the emplacement of peraluminous syntectonic leucogranites and migmatites (e.g. Ballouard et al., 2015; Brown and Dallmeyer, 1996; Gapais et al., 2015).

In addition, different tools (hydrogen and oxygen isotopes of whole rock, minerals and fluid inclusions) applied on diverse geological materials (e.g undeformed and mylonitic granites, host rocks and quartz veins) across the strike-slip South Armorican Shear Zone (Ballouard et al., 2018a; Dusséaux et al., 2019; Lemarchand et al., 2012; Tartèse et al., 2013), within the footwall of nearby detachment zones (Ballouard et al., 2017, 2015; Dusséaux, 2019; Dusséaux et al., 2019) and in kilometer-scale quartz veins cutting through the lower crustal units in the southern Armorican domain (Lemarchand et al., 2012), as well as on shear zones of the western French Massif Central (Dusséaux et al., 2021) that constitutes the SE prolongation of the southern Armorican domain, all agree with the idea that cold meteoric fluids infiltrated the upper plate during Late-Carboniferous extensional processes and reached significant depths $(10-15 \mathrm{~km})$ while mixing with deep crustal fluids. These Earth's surface-derived fluids played a major role in the coupled grain-scale physical and geochemical processes resulting from fluid-rock-deformation interactions that influenced the thermomechanical evolution of Variscan deformation zones and led to the formation of uranium ore deposits (e.g. Ballouard et al., 2017, 2018a; Boulvais et al., 2019).

Here, we present structural, microstructural, electron backscatter diffraction (EBSD) petrofabrics, Ti-in-muscovite thermometry, hydrogen isotope $(\delta \mathrm{D})$, geochemical and geochronological data $\left({ }^{40} \mathrm{Ar} /{ }^{39} \mathrm{Ar}\right.$ and $\left.\mathrm{U}-\mathrm{Th} / \mathrm{Pb}\right)$ from mylonitic leucogranites exposed in the QDZ footwall and associated high-grade metamorphic rocks. This new dataset supports previous premises that surface-derived fluids penetrated the ductile segment of the QDZ at $\sim 320 \mathrm{Ma}$ while at the same time high-grade metamorphic rocks were emplacing in the lower crust. In addition, this study indicates that meteoric fluid-rock-deformation interaction lasted for about 17 million years.

\section{Tectonic context and timing of metamorphism in the southern Armorican domain}

The Armorican Massif (Western France) is part of the Ibero-Armorican arc, which forms the internal zone of the Variscan belt of Western Europe (Figure 1A). Three main domains, characterized by contrasting tectonic, geochronological and metamorphic features, are delimited by two major dextral strike-slip shear zones, the North Armorican Shear Zone (NASZ) to the north and the South Armorican Shear Zone (SASZ) to the south. In contrast to the northern and central domains, the southern domain underwent substantial Carboniferous crustal thickening and high-pressure metamorphism (e.g. Ballèvre et al., 2013). From top to bottom three main units can be identified in the southern domain (Figures 1A and 1B): (1) The upper unit comprising blueschists $\left(1.4-1.8 \mathrm{GPa}, 550^{\circ} \mathrm{C}\right)$ and metavolcanics $(0.8 \mathrm{GPa}, 350$ $400^{\circ} \mathrm{C}$; Bosse et al., 2002; Le Hebel et al., 2002, 2007); (2) The intermediate unit characterized by micaschists that preserved greenschist and amphibolite-facies metamorphism (Bossière, 1988; Goujou, 1992; Triboulet \& Audren, 1988); and (3) The lower unit represented by (Stype) syntectonic leucogranites and high-grade metamorphic rocks $\left(0.8 \mathrm{GPa}, 700-750^{\circ} \mathrm{C}\right.$; Jones and Brown, 1990). Peak high-pressure metamorphism in the upper unit (1.8-2.0 GPa and 450- 
$\left.500^{\circ} \mathrm{C}\right)$ and amphibolite-facies in the intermediate unit $\left(0.9 \mathrm{GPa}\right.$ for $\left.650-700^{\circ} \mathrm{C}\right)$ have been dated between $\sim 370 \mathrm{Ma}$ and $\sim 345 \mathrm{Ma}$, respectively $\left(\mathrm{U} / \mathrm{Pb},{ }^{40} \mathrm{Ar} /{ }^{39} \mathrm{Ar}\right.$ and $\mathrm{Rb} / \mathrm{Sr}$; e.g. (Bosse et al., 2005, 2002; El Korh et al., 2011; Le Hébel et al., 2002; Paquette et al., 2017). Strike-slip ductile shear zones at $\sim 350-345 \mathrm{Ma}$ are responsible for the exhumation of these two units (e.g. Ballèvre et al., 2013; Ballouard et al., 2018b; Bosse et al., 2002, 2005; El Korh et al., 2011; Jegouzo, 1980; Tartèse et al., 2011a, 2011b, 2011c; Tartèse and Boulvais, 2010).

137 In contrast, Late-Carboniferous detachment zones played a major role in the exhumation of migmatites and associated syntectonic leucogranites that form the lower unit, and mark the interface that separates the ductile lower crust from blueschist and metavolcanics systematically located stratigraphically above (e.g. Ballouard et al., 2017, 2015; Brown and Dallmeyer, 1996; Cagnard et al., 2004; Gapais et al., 2015, 1993; Goujou, 1992; Turrillot et al., 2011). In agreement with a high Variscan geothermal gradient $\left(\sim 35^{\circ} \mathrm{C} / \mathrm{km}\right.$, e.g. Vanderhaeghe et al., 2020), extreme thermal gradients across detachment zones (e.g. Gottardi et al., 2013), and gravity modelling (e.g. Gébelin et al., 2006), syntectonic leucogranites, including the Quiberon granite (Figure 1), emplaced at shallow depths ( 3 to $10 \mathrm{~km}$ ) in the footwall of detachment zones by relatively cold $\left(<850^{\circ} \mathrm{C}\right)$ partial melting of metasediments (e.g. Ballouard et al., 2017; Capdevila, 2012; Gapais et al., 2015; Le Hebel et al., 2007). This is consistent with the emplacement conditions estimated for garnet-cordierite-rich syntectonic leucogranites ( 0.5-0.6 GPa, $750-800^{\circ} \mathrm{C}$; Gébelin et al., 2009) that represent the granitic melt fraction of biotite-garnet-sillimanite-cordierite metapelites in the western part of the French Massif Central (SE extension of the southern Armorican domain).

At the scale of the southern domain, detachment shear zones predominantly trend N-S to NWSE and are associated with top-to-the-west sense of shear (e.g. Gapais et al., 2015) observed parallel to the stretching lineations that have orientations that vary locally (see Quiberon: top to the WNW, Sarzeau: top to the ESE and Piriac: top to the NNE on Figure 1A). These nearhorizontal shear zones developed due to WNW-ESE crustal extension and are connected by dextral transfer zones parallel to the SASZ (e.g. Turrillot et al., 2011). Both strike-slip and detachment shear zones were active during the Late-Carboniferous and served as conduits for aqueous fluids and/or melt migration (e.g. Gapais et al., 2015).

\section{Results}

\subsection{Structural study}

\section{$162 \quad 3.1 .1$ Outcrop description}

The Quiberon peninsula provides exceptional exposures of the Quiberon Variscan detachment footwall represented by a $\sim 2 \mathrm{~km}$-thick high-strain zone (Figure 1; Gapais et al., 1993). The contact between the footwall and hanging wall of the QDZ is currently located below sea level at $\geq 500 \mathrm{~m}$ from the coast (Figures 1 and 2C). Therefore, the location of the samples in the footwall was estimated based on their structural position from the hanging wall/footwall contact as it is marked on the geological map of the continental margin (Thinon et al., 2008), and taking into consideration a dip of $\sim 38^{\circ}$ to the WNW for the foliation (see description below and Figures 1 and 2, Table 1). Our study is based on two representative outcrops of coarsegrained mylonitic leucogranite in the Quiberon detachment footwall: 1) QUIB01, located at $\sim 300 \mathrm{~m}$ beneath the QDZ, and 2) QUIB03 at $\sim 322 \mathrm{~m}$ beneath the QDZ. Both outcrops are characterized by a shallow to moderate $\left(10-20^{\circ}\right) \mathrm{WSW}$-dipping foliation (S plane) with a ESEWNW trending stretching lineation highlighted by quartz and muscovite grains $(\sim \mathrm{N} 280)$ (Figures 1 and 2). S-planes, emphasized by sheared feldspar and muscovite grains and quartz ribbons, are affected by C-planes dipping with an angle of $\sim 30^{\circ}$ to the WNW (Figures $1 \mathrm{D}$ and 
2D). The $2-5 \mathrm{~cm}$ spaced C-planes are emphasized by large deformed muscovite $(>0.5 \mathrm{~cm})$ oriented parallel to the shear zone boundary and together with S-planes form shear bands indicating a top-to-the-WNW sense of shear (Figures 2C and 2D). Shear bands form a heterogeneous and anastomosing network that isolates sigmoidal quartz veins and micaschist lenses (Figure 2B).

182 Pegmatites intrude the mylonitic leucogranites in different places and especially between QUIB01 and QUIB03 that form their upper and lower boundaries (Figure 2F). Here, pegmatites are intensively deformed and form corridors from a few centimeters up to 1- to 2-meter thick which are near-parallel to the mylonitic leucogranite foliation (Figure 2F). As observed in the leucogranites, pegmatite and quartz veins display a ESE-WNW stretching lineation marked by tourmaline and quartz grains (Figures 2E and 3A). Based on their spatial geometric relationships with the mylonitic leucogranites and their fabrics indicative of recrystallisation during deformation, we interpret their syntectonic emplacement during the Quiberon detachment activity (samples QUIB03-06; Figure 3A). In the same area, undeformed pegmatites and quartz veins crosscut the mylonitic leucogranite foliation with an angle of 30$50^{\circ}$ (QUIB09; figure 2E). Structurally lower in the section, C-S structures progressively disappear due to an increased heat-flow leading to a high granitic melt fraction with biotite schlieren highlighting the primary near-horizontal foliation (Figure 3B).

In addition to those observed in the lower part of the Quiberon section, migmatitic rocks outcrop further east at Port Navalo (Gapais et al., 1993, 2015). Here, two main rock types characterize these high-grade rocks: biotite-garnet-sillimanite-cordierite metasedimentary gneiss and garnet-cordierite leucogranite. The metasediments, representing the migmatite paleosome/mesosome, display a NNW-SSE striking foliation that dips steeply to the ENE $\left(>65^{\circ}\right)$ and contains a near horizontal stretching lineation defined by cordierite and garnet (Figure 3C). Pressure shadows formed by cordierite-sillimanite-biotite assemblages surround large garnet grains $(>2 \mathrm{~cm}$ ) (Figure 3C). In some places, the garnet-cordierite leucogranite forms dykes near-parallel to the foliation, illustrating the increasing granitic melt fraction from the paleosome/melanosome (Figure 3D). These alternating quartzo-feldspathic-rich (leucosome) and ferromagnesian-rich (paleosome/melanosome) layers are folded and based on the fold axial surface indicate a syn-to-post migmatitic NNE-SSW shortening event (Figure 3D).

\subsubsection{Microstructures}

At the microscopic scale, muscovite mica fish from mylonitic leucogranites (i.e. QUIB01 and QUIB03) develop along both shear (C) and schistosity (S) planes (Figures 4A and 4D). Phyllosilicate mineral cleavages are parallel to $S$ planes and are relatively displaced by $C$ planes made of finely recrystallized material (e.g. Figures 4B, 4E and 4H; Berthé et al., 1979; Lister and Snoke, 1984). Together, they form C-S structures that support the idea that leucogranites were emplaced while the Quiberon detachment was active (Figures 4A and 4D). Overall, C-S structures indicate a top-to-the-WNW sense of shear (Figure 4A), but opposite shear sense can be observed in some leucogranite samples (Figure 4D). Following the mica fish morphological grouping proposed by ten Grotenhuis et al. (2003), the truncated upper and lower parts of lenticular muscovite grains (group 1) indicate that they underwent rotation and solutionprecipitation during deformation (Figure 4F, 4G and 4B). Some of these group 1 muscovite fish evolve into group 2 by drag along micro shear planes that developed along the upper and lower sides of the grain, resulting in bent tips and cleavage planes (Figures 4G). While muscovite grains in sample QUIB01 display clear boundaries (Figures $4 \mathrm{~F}$ and $4 \mathrm{G}$ ), mica fish in sample QUIB03 shows recrystallization of tiny muscovite grains $(<50 \mu \mathrm{m})$ along the rims and in pressure shadows (Figure 4B). In mylonitic leucogranite, tourmaline grains are oriented 
with their long axis parallel to the foliation and perpendicular to the lineation, indicating that they rotated along the shear plane (Figure 4H). Sub-solidus deformation microstructures such as rectangular and castellated quartz grain boundaries (Figures $4 \mathrm{C}$ and $4 \mathrm{I}$ ) indicate that grain boundary migration (regime 3; Hirth and Tullis, 1992) was the dominant dynamic recrystallization process that affected the mylonitic syntectonic leucogranite, reflecting a high recovery: strain accumulation ratio resulting from high-temperature or low strain rate deformation (e.g. Kilian \& Heilbronner, 2017). Feldspar microstructures such as perthite and abundant micro-fracturing indicate both ductile and brittle deformation close to the brittleductile transition for feldspar $\left(\sim 450 \pm 50^{\circ} \mathrm{C}\right)$ and are consistent with a top to the WNW sense of shear (Figures 4A, 4D and 4E). In addition, microfractures, brecciation and sericitization of feldspar and grain boundaries, as well as minor chloritic alteration along biotite grain boundaries and shear planes overprinted the previous deformation fabrics in both mylonitic leucogranite samples and provide evidence for hydrothermal alteration (Figures 4A and 4D).

The ultramylonitic pegmatite displays a foliation (S) supported by fine grains of feldspar and quartz $(<100 \mu \mathrm{m})$ that form ribbons wrapping some remains of K-feldspar porphyroclasts (QUIB04; Figures 5A, 5B and 5C). C-planes marked by mica fish layers make an angle of $\sim 30^{\circ}$ with S-planes. In agreement with microstructures from mylonitic leucogranites, pegmatites display C-S structures depicting a top-to-the-WNW sense of shear that confirm their syntectonic emplacement (e.g. Gapais \& Boundi, 2014). This kinematic inference is supported by drag or quarter folds made by quartz and feldspar-rich layers (Figure 5B) and discontinuous C' shear planes (Figure 5C). This top-to-the WNW kinematic is also strengthen by asymmetric sigmoidal feldspars (Figures 5A and 5D). Biotite in ultramylonitic pegmatite is more frequent than in leucogranite and marks the $0.25 \mathrm{~cm}$-spaced shear planes (Figures 5A, 5B and 5D). The mylonitic foliation is overprinted by lower-grade microstructures. Narrow zones of cataclasite and ultracataclasite developed parallel to the shear plane in mica-poor areas (Figure 5A). Feldspars are commonly affected by fractures that are sometimes filled by muscovite or quartz (Figure 5B, 5D and 5E). Recrystallized quartz surrounds feldspar grains in pressure shadows (Figures 5D and 5E). Also, sericitization of feldspar and muscovite is frequent including in pressure shadows and along shear planes (Figures 5C and 5D).

The observation of high-grade metamorphic rocks at the microscopic scale confirms the presence of biotite, garnet, sillimanite, and cordierite in addition to K-feldspar, plagioclase and quartz in the melanosome/mesosome part (Figure 5F). At the macroscopic scale (Figure 3C), sillimanite and cordierite are observed in pressure shadows around garnet. The leucosome part exhibits a medium-grained fabric $(>1 \mathrm{~mm})$ made of K-feldspar, plagioclase, quartz, biotite, garnet, and large cordierite minerals that form $\sim 50 \%$ of the matrix/sample (Figure $5 \mathrm{G}$ ).

\subsubsection{EBSD on quartz grains}

The crystallographic-preferred orientation (CPO) of quartz grains from sample QUIB01 is used

262 here to obtain information about the quartz slip system operated in mylonitic granite from the QDZ footwall (Figure 6; Text 2 of the supplementary material). As observed in thin section, the quartz grain maps obtained by EBSD reveal sigmoidal quartz ribbons made of quartz grains (re)crystallizing by grain boundary migration (Figures 6A and 6B). Quartz c-axis pole figures exhibit four maxima symmetrically distributed at $\sim 25^{\circ}$ around the shear plane (C) and the lineation direction (Figure 6C), indicating crystal plastic deformation dominated by prismatic (c) glide during coaxial strain with either constriction or plane strain (see framed model on Figure 6 from Barth et al., 2010). The c-axes data also show two maxima located at $\sim 70^{\circ}$ with a monoclinic symmetry to the direction of the lineation which reflect activation of basal [a] slip (e.g. Stipp et al., 2002). The activation of the prismatic <c> slip system is also supported by quartz a-axes that form a single asymmetric girdle indicating a non-coaxial kinematic to the 
WNW (see framed model on Figure 6 from Barth et al., 2010). Based on the a-axes defining a girdle rather than point maxima we propose that deformation occurred more likely under constriction than under plane strain (e.g. Barth et al., 2010). Both quartz c- and a-axes point to the activation of prism $<c>$ glide (e.g. Blumenfeld et al., 1986).

\subsection{Hydrogen isotope geochemistry}

The hydrogen isotope ratios $(\delta \mathrm{D})$ of muscovite and tourmaline from fractions $>250 \mu \mathrm{m}$ were measured in 11 samples of sheared leucogranite, pegmatite, micaschist and quartz veins collected across $300 \mathrm{~m}$ of structural section into the underlying mylonitic footwall of the QDZ (Figure 7 and Table 1). Analyses were performed at the Goethe University-Senckenberg BiKF Stable Isotope Facility, Frankfurt (analytical procedure detailed in Text 1 of the supplementary material). Samples presented here include $\delta \mathrm{D}$ values for muscovite previously reported in Dusséaux et al. (2019).

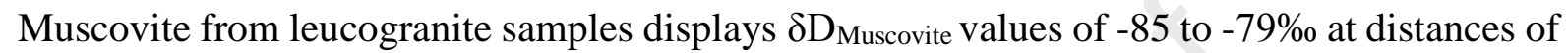

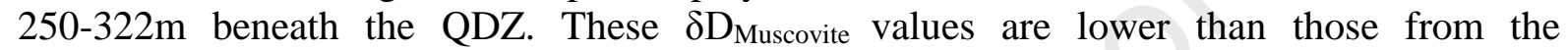

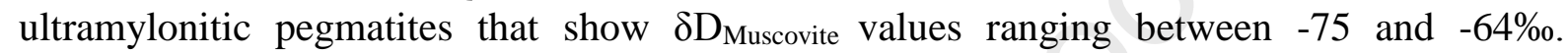
Muscovite from quartz veins and micaschist yields intermediate $\delta \mathrm{D}_{\text {Muscovite values that range }}$ from -80 to $-76 \%$. Tourmaline in leucogranite samples yields lower $\delta \mathrm{D}_{\text {Tourmaline values }}(-87$ to $-86 \%$ ) than those from pegmatites $(-80 \%)$. Tourmaline from quartz veins has intermediate

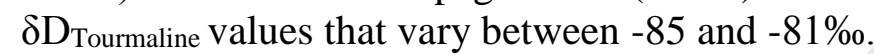

\subsection{Muscovite geochemistry and Ti-in-Ms geothermometry}

293 We measured the chemical composition of muscovite from QUIB01 and QUIB03 to determine

294 (1) the hydrothermal or magmatic origin of muscovite and, (2) the temperature of muscovite 295 crystallization using the Titanium-in-muscovite thermometer (Wu \& Chen, 2015; Text 3 and 296 Table 1 of the supplementary material).

297 We first focused on muscovite from QUIB01 from which the lowest $\delta D_{\text {Muscovite values have }}$ 298 been obtained (-85\%) that were previously interpreted to reflect interaction with surfacederived fluids (Dusséaux et al., 2019). The titanium, magnesium and sodium contents attain values of $0.02<\mathrm{Ti}<0.05 \mathrm{apfu}, 0.08<\mathrm{Mg}<0.10$ apfu and $0.02<\mathrm{Na}<0.03$ apfu, respectively, indicating a magmatic to hydrothermal origin as also highlighted in a Ti-Na-Mg ternary diagram (Figure 8) (Miller et al., 1981). We then focused on muscovite grains from QUIB03

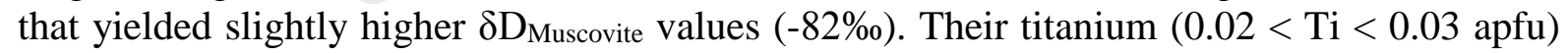
and sodium $(0.02<\mathrm{Na}<0.03 \mathrm{apfu})$ contents are similar to those obtained for the QUIB01 muscovite, but a higher $\mathrm{Mg}$ content $(0.09<\mathrm{Mg}<0.11 \mathrm{apfu})$ makes them plot towards the hydrothermal muscovite field (Figure 8).

307 We then applied the Titanium-in-muscovite thermometer (Ti-in-Ms; Wu and Chen, 2015) to 308 determine the metamorphic temperature conditions using a pressure estimate of $0.4 \pm 0.1 \mathrm{GPa}$ (Text 4 and Table 1 of the supplementary material; e.g. Gapais et al., 1993; Turrillot, 2010). Results from the two samples are consistent with a temperature of $569 \pm 42^{\circ} \mathrm{C}$ for QUIB01 and $546 \pm 41^{\circ} \mathrm{C}$ for QUIB03.

\section{$312 \quad 3.4 \quad \delta$ Dwater values of syntectonic fluids}

313 To calculate the hydrogen isotopic composition of the fluid present during the synkinematic crystallization of muscovite ( $\delta \mathrm{D}_{\text {Water }}$ ), we used the temperatures of $569 \pm 42^{\circ} \mathrm{C}$ and $546 \pm 41^{\circ} \mathrm{C}$ (average $=558 \pm 42^{\circ} \mathrm{C}$ ) determined using the Titanium-in-muscovite thermometer applied for QUIB01 and QUIB03, respectively, which are consistent with temperature estimates deduced from quartz microstructures and quartz c axes fabrics $\left(\sim 550-600^{\circ} \mathrm{C}\right.$; see above). 


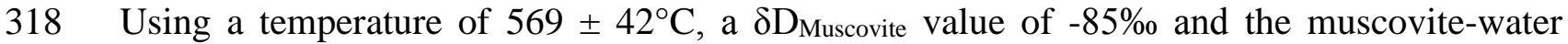

319 hydrogen isotope fractionation factor of Suzuoki and Epstein (1976), we calculated a $\delta D_{\text {Water }}$ 320 value of $-73 \pm 4 \%$ for QUIB01. This value is consistent with the $\delta \mathrm{D}_{\text {Water }}$ value of $-68 \pm 4 \%$ o

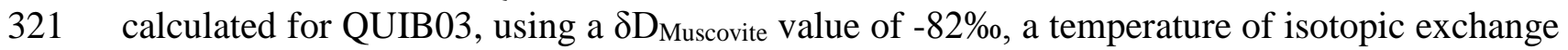
322 of $546 \pm 41^{\circ} \mathrm{C}$ and the hydrogen isotope muscovite-water fractionation of Suzuoki and Epstein 323 (1976).

324 Using the average temperature of $558 \pm 42^{\circ} \mathrm{C}$ obtained from QUIB01 and QUIB03, the equation of Suzuoki and Epstein (1976) and the $\delta D_{\text {Muscovite values of each individual sample }}$

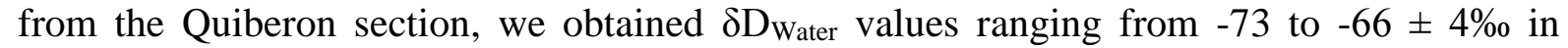
mylonitic leucogranite, from -67 to $-63 \pm 4 \%$ in quartz veins and micaschist, and from -62 to $-51 \pm 4 \%$ in ultramylonitic pegmatite (Table 1). Using the hydrogen isotope composition of tourmaline in equilibrium with muscovite, the hydrogen water-tourmaline isotope fractionation

330 factor of Kotzer et al. (1993) and the average temperature of $558 \pm 42^{\circ} \mathrm{C}$, we calculated $\delta \mathrm{D}_{\text {Water }}$ values ranging from -77 to $-74 \pm 5 \%$ in mylonitic leucogranite, from -74 to $-70 \pm 4 \%$ in quartz veins, and $-69 \pm 4 \%$ in ultramylonitic pegmatite (Table 1 ). The $\delta \mathrm{D}_{\text {Water values calculated from }}$ the $\delta \mathrm{D}_{\text {Tourmaline values }\left(-77 \leq \delta \mathrm{D}_{\text {Water }} \leq-69 \% \text { ) }\right.}$ are 4 to $9 \%$ lower than the ones calculated from the $\delta \mathrm{D}_{\text {Muscovite }}$ values $\left(-73 \leq \delta \mathrm{D}_{\text {Water }} \leq-60 \%\right)$, but both are comparable within uncertainty $(< \pm$ $5 \%$ ).

\subsection{Geochronology}

\section{7}

\subsubsection{Muscovite ${ }^{40} \mathrm{Ar} /{ }^{39} \mathrm{Ar}$ dating of mylonitic leucogranite}

Four single muscovite grains from QUIB01 and QUIB03 were step-heated for ${ }^{40} \mathrm{Ar} /{ }^{39} \mathrm{Ar}$ analyses using a $\mathrm{CO}_{2}$ laser probe coupled with a MAP215 mass spectrometer (Figure 8; Text 5 and Tables 2 and 3 of the supplementary material). The experiments were carried out in Geosciences Rennes, France. The analytical procedure described by Ruffet et al. $(1995,1991)$ is provided as supplementary material (Text 5) with parameters used for calculations (Table 2). Analytical data are available in Table 3 of the supplementary material.

344 Two muscovite grains from QUIB03 provide consistent plateau ages in the $305-303.5 \mathrm{Ma}$ range (mean at $304.1 \pm 1.4 \mathrm{Ma}$ ), calculated over more than $90 \%$ of the total degassed ${ }^{39} \mathrm{Ar}_{\mathrm{K}}$.

346 In contrast, two muscovite grains from QUIB01 yield older ages. One of the grains provides a perfectly flat age spectrum allowing a plateau age to be calculated at $319.5 \pm 1.9 \mathrm{Ma}(2 \sigma)$. The age spectrum obtained on the other grain indicates younger apparent ages, in the range of 306$309 \mathrm{Ma}$, and a characteristic saddle shape which will be discussed below.

\section{0}

\subsubsection{Monazite, zircon and apatite $\mathrm{U}-\mathrm{Th} / \mathrm{Pb}$ dating of leucogranite}

Two samples of weakly deformed (QUIB21) and mylonitic (QUIB20) leucogranite from the QDZ footwall were dated in the GeOHeLiS analytical platform (Univ Rennes 1), France, using zircon, monazite and apatite LA-Q-ICP-MS U(-Th)/Pb dating (See location on the simplified stratigraphic column of Figure 2, Figure 9; Text 6 and Tables 4, 5, 6 and 7 of the supplementary material).

Monazite grains extracted from the weakly deformed leucogranite sample QUIB21 plot in a concordant position in the ${ }^{206} \mathrm{~Pb} /{ }^{238} \mathrm{U}$ versus ${ }^{208} \mathrm{~Pb} /{ }^{232} \mathrm{Th}$ concordia diagram (Figure 9), with apparent ${ }^{206} \mathrm{~Pb} /{ }^{238} \mathrm{U}$ ages ranging from $335 \mathrm{Ma}$ down to $285 \mathrm{Ma}$ (Table 5 of the supplementary material). A group of twelve consistent and concordant analyses yield a date of $318 \pm 2.2 \mathrm{Ma}$ $(\mathrm{MSDW}=0.5$; Figure 9A). Analyses 13 and 22 are within error with this concordant group, although they yield older apparent ages. The remaining data plot along the concordia curve yielding apparent ages between 300 and $285 \mathrm{Ma}$. Apatite grains from the same sample yield a 
${ }^{207} \mathrm{~Pb}$ corrected date of $312.9 \pm 2.2 \mathrm{Ma}(\mathrm{MSDW}=0.5)$ equivalent within error with both the free- $(323 \pm 12 \mathrm{Ma})$ and anchored- $(313.2 \pm 3.3 \mathrm{Ma})$ isochron dates (Figure 9B; Table 7 of the supplementary material). Note that these apatite crystals are characterized by very consistent REE spectra and a U content of $\sim 70$ ppm (Figure 9C).

367 For the more deformed sample QUIB20, 23 measurements out of 34 zircon grains were 368 performed. Plotted in a Tera-Wasserburg diagram (Figure 9D), data are concordant to discordant with ${ }^{206} \mathrm{~Pb} /{ }^{238} \mathrm{U}$ apparent ages ranging from 875 down to $315 \mathrm{Ma}$ (Table 5 of the supplementary material). Three groups of concordant data can be distinguished. The first and oldest group yields a concordant date of $676 \pm 2.3 \mathrm{Ma}(\mathrm{n}=4, \mathrm{Zr} 18$ \& 19), the second a concordant date of $335 \pm 2.3 \mathrm{Ma}(\mathrm{n}=4, \mathrm{Zr} 19 \& 26)$ and the youngest one a concordant date of $317 \pm 4 \mathrm{Ma}(\mathrm{n}=5, \mathrm{MSDW}=1.2 ; \mathrm{Zr} \mathrm{3}, 8,16 \& 19)$. In this sample, the REE spectra for the apatite grains are different from one to the other and associated with a $U$ content of $\sim 50 \mathrm{ppm}$ (Figure 9F). The QUIB20 apatite yield a ${ }^{207} \mathrm{~Pb}$ corrected date of $304.9 \pm 3.2 \mathrm{Ma}(\mathrm{MSDW}=0.9$ ) that is comparable with the free $(310 \pm 14 \mathrm{Ma})$ and anchored $(302.9 \pm 4.3 \mathrm{Ma})$ isochron dates (Figure 9E; Table 7 of the supplementary material).

\subsubsection{Monazite $\mathrm{U}-\mathrm{Th} / \mathrm{Pb} \mathrm{REE}$ petrochronology of migmatite}

The melanosome/mesosome part of the Port Navalo migmatite located in the QDZ footwall was dated and characterized using in-situ laser ablation petrochronology techniques at the University of Portsmouth, UK (Full methodology and results can be found in Text 7 and Tables 8 and 9 of the supplementary material). Sample NAV04 yields a spread of concordant U-Pb analyses (Figures 10A-10D) that range in ${ }^{206} \mathrm{~Pb} /{ }^{238} \mathrm{U}$ and ${ }^{208} \mathrm{~Pb} /{ }^{232} \mathrm{Th}$ apparent age from $\sim 330$ to $290 \mathrm{Ma}(\mathrm{n}=35$; Figure $10 \mathrm{~A})$. This spread is not statistically resolvable into separate populations. All monazite analyses yield consistent trace element signatures, with relative enrichments in LREE, significant Eu anomalies and a slight range in HREE (Figure 10F). Monazite grains show faint zoning in BSE (Figure 10G) and some variation in their Y concentrations (Table 8 of the Supplementary material). However, there is no systematic variation in either REE or Y concentration with age, and in grains where multiple spots were analyzed, they were within uncertainty and therefore non-resolvable.

\section{Discussion}

\section{$392 \quad 4.1 \quad$ Interpretation of geochronological data}

\section{4.1.1 Monazite petrochronology}

394 Monazite grains from both the leucogranite and migmatite analyzed in this study yielded a spread of apparent ${ }^{206} \mathrm{~Pb} /{ }^{238} \mathrm{U}$ ages that almost overlap within uncertainty e.g. $319 \pm 8 \mathrm{Ma}-$ $283 \pm 8 \mathrm{Ma}$ (leucogranite) and $329 \pm 9 \mathrm{Ma}-288 \pm 8 \mathrm{Ma}$ (migmatite). This spread can be interpreted either as $\mathrm{Pb}$ loss, incomplete resetting during fluid-related dissolution precipitation (e.g. Grand'Homme et al., 2016), or due to a genuine spread in geological ages (e.g. Foster et al., 2004, and commonly seen in Himalayan monazite ages). Monazite is resistant to Pb-loss by volume diffusion alone (e.g. Cherniak et al., 2004; Gardés et al., 2007, 2006; Parrish, 1990), however is prone to dissolution-precipitation (recrystallization; e.g. Hetherington et al., 2017). This may result in the formation of patchy zoning at grain scale and discordance in the U-Th$\mathrm{Pb}$ system (e.g. Krohe and Wawrzenitz., 2000; Seydoux-Guillaume et al., 2012; Wawrzenitz et al., 2015) causing disruption of the isotopic age due to incomplete resetting, and a trend of data towards the right of a Tera Wasserburg Concordia diagram (Grand'Homme et al., 2016). Monazites in our studied migmatite sample contain patchy zoning (Figure 10G) that could be interpreted as evidence for dissolution-precipitation or growth zoning. The spread seen in the 
408

409

410

411

412

413

414

415

416

417

418

419

420

421

422

423

424

425

426

427

428

429

430

431

432

433

434

435

436

437

438

439

440

441

442

443

444

445

446

447

448

449

450

451

452

453

data could therefore be interpreted as incomplete resetting or could represent a spread of analyses between two populations. It is not possible within the precision of our dataset to distinguish between these scenarios.

Monazite trace elements in the migmatite yield consistent Eu anomalies that can be interpreted as peritectic monazite crystallization with feldspar from (partial) melt (Figure 10F). This is consistent with observations of selvages of quartz and feldspar and lobate grain boundaries (Figure 10E) as well as the presence of cordierite (Figure 5G) in thin section, microstructures indicative of partial melting within the migmatitic host rock. Together with the U-Th-Pb data, it can be interpreted that monazite grew during melting between 330-290 Ma, either during several stages (e.g. Foster et al., 2004; Mottram et al., 2014), or due to the older peritectic monazite being partially reset during later fluid flow event(s) (e.g. Grand'Homme et al., 2016).

\subsubsection{Interpretation of $\mathrm{Ar} / \mathrm{Ar}$ and $\mathrm{U}(-\mathrm{Th}) / \mathrm{Pb}$ ages}

\subsubsection{Syntectonic leucogranite emplacement in the QDZ footwall}

To determine the timing of meteoric fluid infiltration and subsequent meteoric fluid-rock interactions that occurred in the QDZ footwall, we applied different geochronology methods $\left(\mathrm{U}(-\mathrm{Th}) / \mathrm{Pb}\right.$ on zircon, monazite, apatite and ${ }^{40} \mathrm{Ar} /{ }^{39} \mathrm{Ar}$ on muscovite) to date both highly and weakly deformed leucogranites (see summary in Figure 11).

We interpret the $\mathrm{U}-\mathrm{Th} / \mathrm{Pb}$ age of $318 \pm 3 \mathrm{Ma}$ obtained on monazite from a weakly deformed leucogranite (QUIB21) as its age of emplacement. This age is comparable to the U/Pb age of $317 \pm 4$ Ma obtained on magmatic zircon from a similar but intensively deformed leucogranite (QUIB20) collected at the top of the section that we also interpret to reflect the period of syntectonic emplacement. Both ages are in agreement with the ${ }^{40} \mathrm{Ar} /{ }^{39} \mathrm{Ar}$ age of $319.7 \pm 1.9 \mathrm{Ma}$ $(2 \sigma)$ obtained on muscovite from the QUIB01 mylonitic leucogranite sample (this study), which is similar to the muscovite ${ }^{40} \mathrm{Ar} /{ }^{39} \mathrm{Ar}$ age of $319.2 \pm 1.8 \mathrm{Ma}(2 \sigma)$ obtained in the Questembert granite emplaced along the SASZ (Tartèse et al., 2011b, 2011c).

The similarity of the $\mathrm{U}(-\mathrm{Th}) / \mathrm{Pb}$ and ${ }^{40} \mathrm{Ar} /{ }^{39} \mathrm{Ar}$ ages at $\sim 318 \mathrm{Ma}$ on the weakly and more deformed granite types indicate that following their emplacement, leucogranites have experienced a rapid cooling through the isotopic closure temperature $\left(\mathrm{T}_{\mathrm{c}}\right)$ of argon in muscovite. Based on Harrison et al. (2009)'s experimental determinations of muscovite diffusion coefficients, (Pitra et al., 2010) calculated a $\mathrm{T}_{\mathrm{c}}$ of $\sim 540^{\circ} \mathrm{C}$ for a diffusion radius of 1 $\mathrm{mm}$ and a cooling rate of $100^{\circ} \mathrm{C} / \mathrm{Ma}$. Therefore, our data agree with a rapid cooling and suggest that, as proposed by Gapais et al. (1993), the QDZ may have played a major role in exhuming rocks from the lower unit.

The presence of C-S structures in mylonitic leucogranites within the top $\sim 500 \mathrm{~m}$ of the section supports a syntectonic crystallization age of monazite at $318 \pm 3 \mathrm{Ma}$, and although such fabrics are not clearly observed within the weakly deformed leucogranite from the bottom of the section $(\sim 700 \mathrm{~m})$ and dated at $317 \pm 4 \mathrm{Ma}$ on zircon, the presence of biotite schlieren and their orientations related to the magmatic lineation suggest that they emplaced while the detachment zone was already active. Based on the similarity of the $\mathrm{U}(-\mathrm{Th}) / \mathrm{Pb}$ and ${ }^{40} \mathrm{Ar} /{ }^{39} \mathrm{Ar}$ ages at $\sim 318$ Ma on the weakly and more deformed granite types, we conclude that 1) the QDZ was already active at that time, 2) based on the structural and microstructural features, the mylonitic and weakly deformed leucogranites emplaced during the QDZ activity, and that the deformation was heterogenous over a thickness of $\sim 700 \mathrm{~m}$ with highly deformed rocks at the top and weakly deformed rocks at the bottom.

To help reconstructing the cooling history, we acquired additional ${ }^{40} \mathrm{Ar} /{ }^{39} \mathrm{Ar}$ data from sample QUIB03 from which two muscovite grains yielded two concordant ages of 304.8 $\pm 2.1 \mathrm{Ma}$ and 
$303.4 \pm 2.1 \mathrm{Ma}(2 \sigma)$ (Figure 8). A similar age of $305 \pm 3$ Ma has been obtained on apatite using $\mathrm{U} / \mathrm{Pb}$ geochronology from the mylonitic leucogranite QUIB20. The spread REE spectrum of apatite supports the idea that these minerals experienced a partial leaching of REE during hydrothermal alteration (see Ballouard et al., 2018a).

Although showing a saddle shape spectrum, a single muscovite grain from QUIB01 provides a plateau age of $307.7 \pm 1.7 \mathrm{Ma}$ with apparent ages ranging between $309.0 \pm 1.5 \mathrm{Ma}$ and 305.9 $\pm 1.5 \mathrm{Ma}$. When comparing with the plateau age of $\sim 319.5 \mathrm{Ma}$ provided by a single muscovite grain from the same sample (see above), these ages are younger and close to those obtained from the QUIB03 muscovite and QUIB20 apatite grains (Figure 11). It is known that the partial re/neo-crystallization of white mica can generate saddle-shaped age spectra that result from distinctive degassing patterns of the initial/inherited and re/neo-crystallized domains for a given crystal (see Alexandrov et al., 2002; Castonguay et al., 2007; Cheilletz et al., 1999; Tartèse et al., 2011c; Tremblay et al., 2011). The observed saddle shape can result from two distinct phenomena: (1) the mixing of two distinct radiogenic components that are imperfectly separated, an initial/inherited one which could be as old as $\sim 319.5 \mathrm{Ma}$ and a re/neo-crystallized one which could be as young as $\sim 304 \mathrm{Ma}$; (2) the isotopic record of period of long protracted recrystallization history from $\sim 309$ to $306 \mathrm{Ma}$ linked to deformation and/or fluids. However, the relatively young ages obtained for mylonitic leucogranite (QUIB03 muscovite ${ }^{40} \mathrm{Ar} /{ }^{39} \mathrm{Ar}$ ages of $\sim 305$ and $\sim 303.5 \mathrm{Ma}$ and QUIB20 apatite $\mathrm{U} / \mathrm{Pb}$ age of $\sim 305 \mathrm{Ma}$ ) and the associated apatite REE and muscovite $\delta \mathrm{D}$ results seem to be in favor of the second option, involving the syntectonic fluid-assisted (re)crystallization of mica through time.

Apatite from weakly deformed leucogranites (QUIB21) yielded a U/Pb date of $313 \pm 2 \mathrm{Ma}$. In agreement with the magmatic structures observed at the mesoscopic scale on the weakly deformed leucogranite (Figure 3B), apatite display a narrow REE distribution pattern. Based on the theoretical closure temperature of apatite ranging between 350 and $550^{\circ} \mathrm{C}$ (e.g. Chew and Spikings, 2015; Pochon et al., 2016), we interpret this U/Pb date of $313 \pm 2 \mathrm{Ma}$ as a cooling age.

To summarize, two main events can be defined from these geochronological results:

1) An early phase at $\sim 318 \mathrm{Ma}$ (U-Th/Pb on monazite and $\mathrm{U} / \mathrm{Pb}$ on magmatic zircon) marked by leucogranite emplacement in the Quiberon detachment footwall while the shear zone was active. Following their emplacement, these leucogranites ensued a rapid cooling as highlighted by ${ }^{40} \mathrm{Ar} /{ }^{39} \mathrm{Ar}$ ages from the QUIB01 muscovite grains.

2) A late phase at $~ 305 \mathrm{Ma}$ characterized by a main magmatic-hydrothermal event highlighted by apatite $\mathrm{U} / \mathrm{Pb}$ and muscovite ${ }^{40} \mathrm{Ar} /{ }^{39} \mathrm{Ar}$ ages, and apatite REE spectra and uranium content from mylonitic leucogranites. Both apatite $\mathrm{U} / \mathrm{Pb}$ and muscovite ${ }^{40} \mathrm{Ar} /{ }^{39} \mathrm{Ar}$ ages of $\sim 305 \mathrm{Ma}$ are in agreement with previous published muscovite ${ }^{40} \mathrm{Ar} /{ }^{39} \mathrm{Ar}$ ages between $\sim 304$ and $301 \mathrm{Ma}$ measured in similar mylonitic leucogranite from Quiberon (Gapais et al., 2015; Turrillot, 2010) and $\mathrm{U} / \mathrm{Pb}$ ages of $\sim 303 \mathrm{Ma}$ acquired on zircon and monazite from an aplitic dyke of the neighboring Guérande leucogranite (Ballouard et al., 2015).

\subsubsection{Migmatization in the QDZ footwall}

$\mathrm{U}-\mathrm{Th} / \mathrm{Pb}$ monazite from the Port Navalo migmatite provided a spread of apparent ages between 330-290 Ma. A more precise age would be useful to explore the exact tectonomagmatic and metamorphic link between the migmatites and leucogranites. However, our relatively imprecise age range demonstrates that the lower-crustal migmatites were partially melting while monazite crystallized coevally in the syntectonic leucogranite. Our dates also suggest that there was several (tens) of millions of years of metamorphism and fluid-flow that potentially (partially) reset the ages. This is consistent with a lower-crustal setting where rocks 
are deformed, metamorphosed and experience partial melting in the presence of fluids over prolonged periods of time (such as in the Himalaya; Mottram et al., 2014).

\subsection{Syntectonic hydrothermal alteration during high-temperature deformation}

\subsubsection{Source of fluids}

505

506

507

508

509

510

511

512

513

514

515

516

517

518

519

520

521

522

523

524

525

526

527

528

529

530

531

532

533

534

535

536

537

538

539

540

Hydrogen isotopes measured on syntectonic muscovite from mylonitic leucogranite, ultramylonitic pegmatite and quartz veins allow to calculate $\delta D_{\text {Water }}$ values from -73 to $-51 \pm$ $5 \%$ that correspond to the hydrogen isotopic composition of water that equilibrated with muscovite in the detachment footwall (Table 1). Muscovite from mylonitic leucogranite samples provides the lowest calculated $\delta D_{\text {water }}$ values $(-73$ to $-66 \%$ ) whereas the highest $\delta D_{\text {Water }}$ values (-62 to $-51 \%$ ) have been obtained from muscovite from ultramylonitic

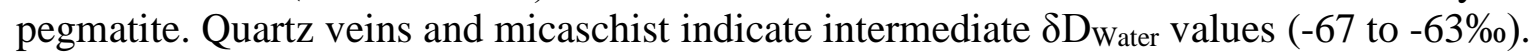

The difference of up to $22 \%$ between the $\delta \mathrm{D}_{\text {Water }}$ values extracted from the Quiberon mylonitic leucogranites and ultramylonitic pegmatites allow to identify two different reservoirs of fluids that have triggered intense fluid-rock interactions in the Quiberon detachment footwall. The new hydrogen dataset presented here extracted from various lithologies from the QDZ footwall (Figure 7) is in good agreement with the results published in Dusséaux et al. (2019) showing a regional-scale mixing relationship between deep crustal fluids ( $\delta \mathrm{D}_{\text {Water }}$ values up to $-33 \%$ ) and surface-derived fluids ( $\delta D_{\text {Water }}$ values down to $-74 \%$ ) in syntectonic leucogranite emplaced at different crustal levels in the southern Armorican domain. Fluid inclusions aligned along synkinematic structural planes in quartz grains from detachment footwalls (Quiberon and Piriac; Dusséaux, 2019) contain very low to medium salinity water (0 to $7 \mathrm{wt} \%$ eq. $\mathrm{NaCl}$ ) and yield $\delta \mathrm{D}$ and $\delta^{18} \mathrm{O}$ values plotting between the meteoric water line and the metamorphic/magmatic ranges, further strengthening this interpretation. This mixing relationship has also been demonstrated based on $\delta \mathrm{D}_{\text {water }}$ values from syntectonic leucogranites, pegmatites, quartz veins and episyenites in the western part of the French Massif Central (merging to the northwest with the southern Armorican domain) where high $\delta \mathrm{D}_{\text {water }}$ values of up to $\sim-30 \%$ reveal a signature of deep crustal fluids and $\delta \mathrm{D}_{\text {water }}$ values as low as $-104 \%$ indicate a contribution of meteoric fluids sourced at high elevation (Dusséaux et al., 2021; Turpin et al., 1990).

In the Iberian Massif, other studies involving measurements of hydrogen and oxygen isotope ratios of hydrous minerals (phengite, chlorite) from altered granites and host metasediments (Rodríguez-Terente et al., 2018), or fluid inclusions from granite, mineralized veins and skarns (Tornos et al., 2000) systematically point to the mixing of fluids from different sources (magmatic/metamorphic and meteoric). For instance, $\delta \mathrm{D}_{\text {Water }}$ values from barren quartz veins ranging from -70 to $-35 \%$ are interpreted to reflect strong meteoric water/rock interactions in the Iberian Massif (Martín Crespo et al., 2002). As a consequence, based on previous studies conducted in similar geological objects, the hydrogen isotope values obtained from syntectonic muscovite from the Quiberon granite are consistent with a mixing relationship between deuterium-depleted fluids and metamorphic/magmatic water with high $\delta \mathrm{D}$ values.

Due to the presence of graphite in the overlying micaschist, metavolcanics and quartz veins of the upper crust (e.g. Ballouard et al., 2017; Caroff et al., 2016), we cannot rule out the possibility that graphite crystallization from a methane-bearing fluid could have played a role in lowering the $\delta D_{\text {Muscovite }}$ values from the Quiberon granitic samples (see Craw, 2002). However, the significant number of previous geochemical studies conducted in the southern Armorican domain and the western French Massif Central (See introduction, Ballouard et al., 2015, 2017, 2018a; Dusséaux, 2019; Dusséaux et al., 2019, 2021; Lemarchand et al., 2012; Tartèse et al., 2012, 2013), constitute a tangible proof that meteoric fluids penetrated the 
extending and fractured upper crust to significant depths in the active footwall of detachment zones during the Late Carboniferous, sometimes leading to the formation of uranium ore deposits (Ballouard et al., 2017; Boulvais et al., 2019).

551

552

553

554

555

556

557

558

559

560

561

562

563

564

565

566

The $\delta \mathrm{D}_{\text {Water }}$ values found in pegmatites $\left(-62 \leq \delta \mathrm{D}_{\text {Water }}\right.$ values $\leq-51 \%$ ) are typical of deep crustal fluids $\left(-70 \%\right.$ o $<\delta \mathrm{D}_{\text {metamorphic fluids }}<-20 \%$ and $/$ or $-80 \%$ o $<\delta \mathrm{D}_{\text {magmatic fluids }}<-40 \%$; e.g. Field and Fifarek, 1985). However, the $11 \%$ difference (-62 to $-51 \%$ ) within the $\delta \mathrm{D}_{\text {Water }}$ values can be explained by variable meteoric fluid-rock ratios (e.g. Dusséaux et al., 2019). In a rockbuffered system, pegmatites that intruded mylonitic leucogranites during the latest stages of deformation may not have had enough time to equilibrate with meteoric fluids. In accordance with pegmatite successive emplacement during syntectonic crystallization of late magmatic fluids (Gapais \& Boundi, 2014) and the regional-scale mixing relationship of Dusséaux et al. (2019), we consider that the highest $\delta D_{\text {Water }}$ value of $-51 \%$ most closely approximate the hydrogen isotope composition of a magmatic fluid.

In contrast, the lowest $\delta D_{\text {Water }}$ values $(-73$ to $-66 \%$ ) obtained from mylonitic leucogranite suggest that muscovite interacted with surface-derived deuterium-depleted fluids during deformation (Dusséaux et al., 2019). As mentioned above, lozenge-shaped muscovite grains

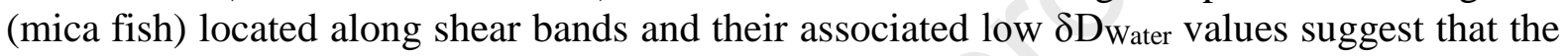
growth of micas occurred through solution-precipitation mechanisms during the QDZ activity which was the site of intense meteoric water-rock interaction. These low $\delta \mathrm{D}_{\text {Water }}$ values are strengthened by those down to $-77 \%$ obtained from tourmaline in mylonitic leucogranite (Figure 7). In agreement with a $\sim 5 \%$ difference in hydrogen isotope fractionation between the muscovite and the tourmaline at $550^{\circ} \mathrm{C}$ and $0.3 \mathrm{GPa}$ (Blamart et al., 1989), the $\delta \mathrm{D}_{\text {Tourmaline }}$ values are systematically 3 to $7 \pm 2 \%$ lower than the $\delta D_{\text {Muscovite values (Figure } 7 \text { and Table } 1 \text { ) }}$ indicating that these two minerals have reached hydrogen isotope equilibrium during hightemperature deformation. These $\delta \mathrm{D}_{\text {Water }}$ values down to $-77 \%$ o corroborate previous studies that interpreted $\delta D_{\text {Water }}$ values down to $-74 \%$ provided by syntectonic leucogranites to reflect an interaction with meteoric fluids during the activity of the Piriac and Quiberon detachment zones

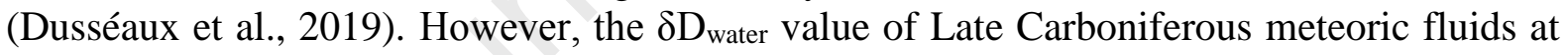
the surface may have been more negative than $-74 \%$ o due to deuterium enrichment during the downward penetration of meteoric and consequent meteoric fluid- rock interactions at low meteoric-fluid rock ratios (e.g. Dusséaux et al., 2021; Gébelin et al., 2012).

\subsubsection{Timing and duration of fluid-rock interactions}

Four lines of evidences lead us to conclude that the 319 Ma muscovite samples (QUIB01; Figure 11) crystallized in presence of meteoric fluids during high temperature deformation in the QDZ footwall: (1) muscovite from this sample provides the lowest $\delta D_{\text {Muscovite value }(-85 \% \text {; }}$ Figure 7), which is $22 \%$ lower than the ones in pegmatite, and has been interpreted to reflect the highest meteoric fluid-rock ratio found in the QDZ footwall (Dusséaux et al., 2019); (2) recrystallization involving solution-precipitation is indicated by primary lenticular mica fish (Group 1; ten Grotenhuis et al., 2003) that evolved through time into a more bent secondary mica fish with deflected tips due to continuous shearing (Group 2; ten Grotenhuis et al., 2003) (Figure 4); (3) the chemical composition of these mica fish plot in both the primary and secondary muscovite fields $(0.02<\mathrm{Ti}<0.05$ apfu; Figure 8$)$; (4) the Ti-in-muscovite thermometry results obtained from muscovite fish associated with low $\delta \mathrm{D}_{\text {Muscovite values }}$ (Figure 7) indicated that they formed during high temperature deformation $\left(>500^{\circ} \mathrm{C}\right)$ which is consistent with quartz grain boundary migration. Therefore, we conclude that $319.5 \pm 1.9 \mathrm{Ma}$ represents a minimum argon age for the infiltration of meteoric fluids which interacted with synkinematic muscovite during high temperature deformation in the QDZ footwall. 
Lenticular muscovite grains from the QUIB03 sample provide younger ${ }^{40} \mathrm{Ar} /{ }^{39} \mathrm{Ar}$ ages of $\sim 305$ - $303 \mathrm{Ma}$ (Figure 11) that could reflect a period of intense hydrothermal activity because (1)

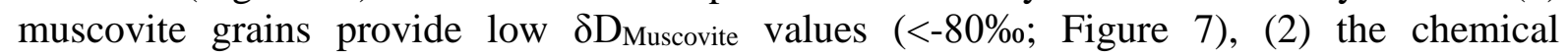
composition of these mica fish have a tendency to plot into the field of hydrothermal muscovite $(0.02<\mathrm{Ti}<0.03 \mathrm{apfu})$, (3) group 1 mica fish (ten Grotenhuis et al., 2003) show evidence of secondary newly recrystallized grains on the grains boundaries, (4) apatite from the same mylonitic leucogranites that yield similar ages (305 $\pm 4 \mathrm{Ma}$; Figure 9) are associated with varied REE spectra reflecting hydrothermal alteration.

603 We propose that meteoric fluid-rock interactions occurred in the footwall of the QDZ during 604 high-temperature deformation at least between $319.5 \pm 1.9 \mathrm{Ma}$ and $303.4 \pm 2.1 \mathrm{Ma}$, supported 605 by syntectonic mica growth (see section 4 above; e.g. Gébelin et al., 2011; Kelley, 2002; 606 Tartèse et al., 2011b).

607 Field observations show that the walls of planar ultramylonitic pegmatite veins form an angle 608 of $\sim 10^{\circ}$ with mylonitic leucogranite foliation suggesting syntectonic pegmatite emplacement within the high strain zone while the ductile deformation was still active (Figure $2 \mathrm{~F}$ ). The high $\delta D_{\text {Water }}$ values calculated from syntectonic muscovite from deformed pegmatites ranging from $-62 \%$ to $-51 \%$ do not reflect a meteoric fluid signature but rather a magmatic imprint. By comparison with mylonitic leucogranites from which $\delta D_{\text {Water }}$ values between -77 and $-66 \%$ have been deduced, we interpret the difference in reconstructed hydrogen isotopic composition of meteoric water to reflect a difference in microstructure, chemical composition and permeability of the rock and/or a short period of meteoric fluid-rock interactions.

616 The geochronological results presented in this study do not preclude the possibility that 617 meteoric fluid infiltration and detachment activity may have occurred before $\sim 320 \mathrm{Ma}$ and/or 618 after $\sim 303 \mathrm{Ma}$. The $\delta \mathrm{D}$ values measured in leucogranite can be interpreted as the presence of surface-derived fluids in the footwall during this time period (see paragraph 4.2.1). In addition, sericitization along muscovite rims and in pressure shadows in mylonitic leucogranite (e.g. Figure 4B) support fluid-assisted dissolution-precipitation during the final stages of the QSZ activity as indicated by ${ }^{40} \mathrm{Ar} /{ }^{39} \mathrm{Ar}$ ages of $\sim 305$ and $\sim 303.5 \mathrm{Ma}$. Moreover, both mylonitic and cataclastic fabrics revealed in mylonitic leucogranite and pegmatite reveal a normal sense of movement suggesting that brittle fabrics formed during exhumation of metamorphic footwall rocks to the hanging wall along the Quiberon detachment zone while syntectonic granites were crossing the brittle-ductile transition. A late, intense fluid circulation event sustained by high (paleo-) geothermal gradient likely occurred in the Quiberon detachment footwall until 298 $\mathrm{Ma}$ as indicated by monazite $\mathrm{U} / \mathrm{Pb}$ dates of $297 \pm 8 \mathrm{Ma}$ and $298 \pm 8 \mathrm{Ma}$ from the Port Navalo migmatites (Figure 10) and shown by $\sim 298$ Ma muscovite ${ }^{40} \mathrm{Ar} /{ }^{39} \mathrm{Ar}$ ages obtained on late shear bands and deformed pegmatite from the Quiberon peninsula (Gapais et al., 2015; Turrillot, 2010).

\section{$632 \quad$ 4.2.3 Implications for elemental mobility}

633 REE spectra from apatite grains show a difference in the uranium content from high ( $70 \mathrm{ppm})$ 634 in the weakly deformed granite to low $(\sim 50 \mathrm{ppm})$ in the mylonitic leucogranite. Based on the ages obtained for these two granites, we can say that the uranium content decreased through time from at least $\sim 313 \mathrm{Ma}$ (QUIB21) to $\sim 305 \mathrm{Ma}$ (QUIB20). These observations agree with the deuterium depletion in muscovite and tourmaline identified in the younger granite, associated to a spread REE spectrum reflecting REE partial leaching from apatite. Therefore, we propose that the depletion in uranium and rare earth elements in apatite and in deuterium detected in muscovite and tourmaline are related to a same fluid-rock interaction event that occurred during the final stage of the Quiberon magmatic-hydrothermal system activity. This 
agrees with studies of uranium deposits in the southern Armorican domain (e.g. Ballouard et al., 2017, 2018a, 2018b; Boulvais et al., 2019; Tartèse et al., 2013) showing that meteoric fluids leached uranium from the magmatic uraninite in syntectonic peraluminous granites emplaced in the footwall of detachments (Piriac, and in this study, Quiberon) or along the SASZ (e.g. Pontivy, Questembert). On their way back to the surface, the oxidized uranium-bearing fluids interacted with reducing black schists and triggered the precipitation of hydrothermal uraninite. At the broader scale of the Variscan belt of Western Europe, coeval late-orogenic extensional shear zones, hydrothermal fluid flow, leucogranite syntectonic emplacement and granulitefacies metamorphism in the lower crust led to $\mathrm{U}, \mathrm{W}, \mathrm{Au}, \mathrm{Sb}, \mathrm{P}$ and rare earth element mineralization (e.g. Ballouard et al., 2017; Boiron et al., 2003; Bouchot et al., 2005; Cuney et al., 2002; Cuney, 2014; Harlaux et al., 2018).

\section{3}

\subsection{Mechanisms and depth of meteoric fluid infiltration}

The infiltration of surface-derived fluids down to the detachment footwall could be explained through fractures and steep normal faults (Figure 2A) that developed in the extending brittle upper crust and soled down on to the QDZ (e.g. Gébelin et al., 2017, 2015, 2013, 2011; Mulch et al., 2006, 2004; Person et al., 2007). In addition to brittle structures that could have served as conduits for fluids and generated the necessary porosity for fluid percolation from the surface down to the middle crust, anastomosing C-S structures (Figures 2, 4 and 5) localize the strain, weaken the rock and promote permeability (e.g. Bauer et al., 2000; Hunter et al., 2016; McCaig, 1988; Tartèse et al., 2013). Meteoric fluid infiltration to substantial depths involves the presence of both hydraulic (e.g. Person et al., 2007) and hydrostatic heads (e.g. Sutherland et al., 2017; Upton \& Sutherland, 2014) and can be achieved through dip slip faulting-related dilatancy (e.g. Nüchter and Ellis, 2011) that episodically injects small amount of meteoric fluids and leads to protracted periods of fluid-rock interactions (e.g. Sibson, 1981; Upton et al., 1995) in agreement with our rock- buffered meteoric fluid signatures.

667

668

669

670

In addition, driving forces are essential to maintain fluid-rock interactions for more than $15 \mathrm{Ma}$ in the active ductile segment of the QDZ. As suggested for other fossil hydrothermal systems (e.g. Gébelin et al., 2011, 2015, 2017; Methner et al., 2015; Person et al., 2007), advection of partially molten materials in the lower crust can sustain buoyancy-driven fluid convection while the detachment is active and continuously exhume rocks from the footwall to the hanging wall. Together with radioactive heat production (e.g. Jolivet et al., 1989; Vigneresse et al., 1989), partial melting and leucogranite emplacement in the southern Armorican domain from $\sim 320$ to $305 \mathrm{Ma}$ (Figure 11; e.g. Augier et al., 2015; Ballouard, 2016; Ballouard et al., 2018a; Lemarchand et al., 2012; Peucat, 1983; Tartèse et al., 2012, 2011a, 2011c; Turrillot et al., 2011, 2009; Turrillot, 2010), the new U- $\mathrm{Th} / \mathrm{Pb}$ ages acquired on the Port Navalo migmatites ranging from $\sim 330$ to $\sim 290$ Ma (Figure 10) suggest that high heat flow occurred at the same time as the mylonitization across the $\mathrm{QDZ}\left({ }^{40} \mathrm{Ar} /{ }^{39} \mathrm{Ar}\right.$ on muscovite and $\mathrm{U} / \mathrm{Pb}$ on apatite and monazite from the leucogranite; Figures 8 and 9), helping to sustain the hydrothermal system.

680 Coeval lower crustal migmatization and syntectonic leucogranite emplacement has been dated in similar rocks at $\sim 315 \mathrm{Ma}$ in the western part of the French Massif Central that constitutes the eastern extent of the southern Armorican domain (e.g. Gébelin et al., 2009). In the broader framework of the Variscan belt, the results from this study fit well with coeval syntectonic leucogranite emplacement along ductile shear zones and lower crustal partial melting recognized widely in the European Variscan hinterlands at the end of the Carboniferous (e.g. Ballouard et al., 2015; Gébelin et al., 2009; López-Moro et al., 2012; Padovano et al., 2014; Rolland et al., 2009; Tartèse et al., 2012). Age-equivalent migmatization and leucogranite emplacement was also recognized in the Montagne Noire (southern part of the French Massif 
689 Central), considered as the foreland of the belt (e.g. Pitra et al., 2021; Poujol et al., 2017;

690 Whitney et al., 2015).

691 A hydraulic head generated in high-relief areas is also essential for the penetration of surface-

692

693

694

695

696

697

698

699

700

701

702

703

704

705

706

707

708

709

710

711

712

713

714

715

716

717

718

719

720

721

722

723

724

725

726

727

728

729

730

731

732

733 derived fluids at depth. As demonstrated by stable isotope paleoaltimetry estimates for the western French Massif Central (minimum mean elevation of $3400 \pm 700 \mathrm{~m}$; Dusséaux et al., 2021), the Variscan Belt of Western Europe was standing at high elevation during the late Carboniferous. These paleoaltimetry results cannot necessarily be applied to our study area that represents the north-western extension of the French Massif Central. However, based on the internally thickened crust (e.g. Ballèvre et al., 2013) and preliminary stable isotope paleoaltimetry results indicating a mean paleoelevation of $\sim 2500 \mathrm{~m}$ for the southern Armorican domain (Dusséaux, 2019), this region probably imposed a high regional hydraulic head that allowed fluids to migrate down to the brittle-ductile transition and reach the QDZ footwall (e.g. Gébelin et al., 2013, 2012; Raphaël Gottardi et al., 2013; Person et al., 2007).

Although it is difficult to define accurately the depth of meteoric water incursion, we propose that meteoric fluids reached the brittle-ductile transition zone at a depth of $\sim 8 \mathrm{~km}$ based on a $300^{\circ} \mathrm{C}$ isotherm approximately corresponding to the start of brittle-ductile deformation in quartzo-feldspathic rocks (Stöckhert et al., 1999) and a warm Variscan geothermal gradient of $\sim 35-40^{\circ} \mathrm{C} / \mathrm{km}$ (e.g. Vanderhaeghe et al., 2020). However, the local depth of the brittle-ductile transition may be shallower as the active QDZ together with hot material advection may have led to extreme geothermal gradient and tight isotherms across the detachment zone (e.g. Gottardi et al., 2011; Gébelin et al., 2011).

\section{Conclusion}

This study documents the infiltration of meteoric fluids in the footwall of one of the best exposed Variscan extensional shear zones, the Quiberon detachment (QDZ) in the southern domain of the Armorican Massif (France). Combined structural, hydrogen isotope, geochemical and geochronological data from syntectonic leucogranites emplaced in the QDZ footwall allow meteoric fluid-rock interactions at depth to be bracketed between $~ 320$ and 303 Ma. Synkinematic hydrous minerals recrystallized and equilibrated in the QDZ footwall with deuterium-depleted water during high temperature deformation $\left(\sim 500^{\circ} \mathrm{C}\right)$ deduced from microstructural observations and titanium-in-muscovite thermometry. Mica fish provide ${ }^{40} \mathrm{Ar} /{ }^{39} \mathrm{Ar}$ ages between $\sim 320$ and $\sim 303 \mathrm{Ma}$ that, together with microstructural observations, suggest that fluid-rock interactions occurred for at least $17 \mathrm{Ma}$. This interpretation is in good agreement with $\mathrm{U}(-\mathrm{Th}) / \mathrm{Pb}$ data obtained on magmatic zircon and monazite from the same leucogranites that indicate an age of emplacement of $318 \mathrm{Ma}$. In addition, U/Pb ages, REE spectra and uranium content of apatite in leucogranites strengthen the idea that meteoric fluidrock interactions occurred for several million years and played a major role in leaching uranium at $305 \pm 3 \mathrm{Ma}$. U-Th/Pb ages from $\sim 330$ to $290 \mathrm{Ma}$ acquired on migmatites that form the lower crust suggest that, as demonstrated in Metamorphic Core Complexes of the Western part of the US (e.g. Gébelin et al., 2015, 2011; Mulch et al., 2004), high heat flow below the detachment is essential to sustain convection of fluids at depth while the upper crust undergoes extension as demonstrated by brittle fractures and late shear bands dated at $\sim 302-298 \mathrm{Ma}$ (Gapais et al., 2015; Turrillot, 2010).

\section{Acknowledgments}

$\mathrm{CD}$ acknowledges a $\mathrm{PhD}$ studentship from the University of Plymouth. $\mathrm{YB}$ and $\mathrm{NC}$ acknowledge support from NEEDS URAMOD for apatite analyses. The authors are grateful to 
J. Fiebig for laboratory support and to R. Gottardi for constructive comments on an earlier version of the manuscript. The authors acknowledge the thoughtful and constructive comments and suggestions by the editor Virginia Toy and reviewers Bernhard Grasemann and David Craw that greatly improved the manuscript.

\section{References}

Alexandrov, P., Ruffet, G., \& Cheilletz, A. (2002). Muscovite recrystallization and saddleshaped $40 \mathrm{Ar} / 39 \mathrm{Ar}$ age spectra: example from the Blond granite (Massif Central, France). Geochimica et Cosmochimica Acta, 66(10), 1793-1807. https://doi.org/10.1016/S0016-7037(01)00895-X

Augier, R., Choulet, F., Faure, M., \& Turrillot, P. (2015). A turning-point in the evolution of the Variscan orogen: the ca. 325 Ma regional partial-melting event of the coastal South Armorican domain (South Brittany and Vendée, France). Bulletin de La Société Géologique de France, 186(2-3), 63-91. https://doi.org/10.2113/gssgfbull.186.2-3.63

Ballèvre, M., Bosse, V., Dabard, M., Fourcade, S., Paquette, J., Peucat, J., \& Pitra, P. (2013). Histoire géologique du Massif armoricain: actualité de la recherche. Bull. Soc. Géol. Minéral. Bretagne, 10-11(D), 5-96. https://hal-insu.archives-ouvertes.fr/insu-00873116

Ballouard, C., Boulvais, P., Poujol, M., Gapais, D., Yamato, P., Tartèse, R., \& Cuney, M. (2015). Tectonic record, magmatic history and hydrothermal alteration in the Hercynian Guérande leucogranite, Armorican Massif, France. Lithos, 220-223, 1-22. https://doi.org/10.1016/j.lithos.2015.01.027

Ballouard, C., Poujol, M., Boulvais, P., Mercadier, J., Tartèse, R., Venneman, T., Deloule, E., Jolivet, M., Kéré, I., Cathelineau, M., \& Cuney, M. (2017). Magmatic and hydrothermal behavior of uranium in syntectonic leucogranites: The uranium mineralization associated with the Hercynian Guérande granite (Armorican Massif, France). Ore Geology Reviews, 80(July), 309-331. https://doi.org/10.1016/j.oregeorev.2016.06.034

Ballouard, C., Poujol, M., Mercadier, J., Deloule, E., Boulvais, P., Baele, J. M., Cuney, M., \& Cathelineau, M. (2018a). Uranium metallogenesis of the peraluminous leucogranite from the Pontivy-Rostrenen magmatic complex (French Armorican Variscan belt): the result of long-term oxidized hydrothermal alteration during strike-slip deformation. Mineralium Deposita, 53(5), 601-628. https://doi.org/10.1007/s00126-017-0761-5

Ballouard, C., Poujol, M., \& Zeh, A. (2018b). Multiple crust reworking in the French Armorican Variscan belt: implication for the genesis of uranium-fertile leucogranites. International Journal of Earth Sciences, 107(7), 2317-2336. https://doi.org/10.1007/s00531-018-1600-3

Ballouard, Christophe. (2016). Origine, évolution et exhumation des leucogranites peralumineux de la chaîne hercynienne armoricaine : implication sur la métallogénie de l'uranium. Ph.D. thesis, Université Rennes 1.

Barth, N. C., Hacker, B. R., Seward, G. G. E., Walsh, E. O., Young, D., \& Johnston, S. (2010). Strain within the ultrahigh-pressure Western Gneiss region of Norway recorded by quartz CPOs. Geological Society, London, Special Publications, 335(1), 663-685. https://doi.org/10.1144/SP335.27

Bauer, P., Palm, S., \& Handy, M. R. (2000). Strain localization and fluid pathways in mylonite: inferences from in situ deformation of a water-bearing quartz analogue (norcamphor). Tectonophysics, 320(2), 141-165. https://doi.org/10.1016/S0040-1951(00)00065-2

Beaudoin, G., Taylor, B. E., \& Sangster, D. F. (1991). Silver-lead-zinc veins, metamorphic core complexes, and hydrologic regimes during crustal extension. Geology, 19(12), 1217. https://doi.org/10.1130/0091-7613(1991)019<1217:SLZVMC>2.3.CO;2

Berthé, D., Choukroune, P., \& Jegouzo, P. (1979). Orthogneiss, mylonite and non coaxial 

Structural Geology, 1(1), 31-42. https://doi.org/10.1016/0191-8141(79)90019-1

Blamart, D., Pichavant, M., \& Sheppard S.M.F. (1989). Détemination du fractionnement isotopique $\mathrm{D} / \mathrm{H}$ entre tourmaline et eau à $600,500 \mathrm{C}$ et $3 \mathrm{~Kb}$. Comptes Rendus de l'Académie Des Sciences (Paris), 308(II), 39-44.

Blumenfeld, P., Mainprice, D., \& Bouchez, J. L. L. (1986). C-slip in quartz from subsolidus deformed granite. Tectonophysics, 127(1-2), 97-115. https://doi.org/10.1016/00401951(86)90081-8

Boiron, M. C., Cathelineau, M., Banks, D. A., Fourcade, S., \& Vallance, J. (2003). Mixing of metamorphic and surficial fluids during the uplift of the Hercynian upper crust: Consequences for gold deposition. Chemical Geology, 194(1-3), 119-141. https://doi.org/10.1016/S0009-2541(02)00274-7

Bosse, V., Ballèvre, M., \& Vidal, O. (2002). Ductile thrusting recorded by the garnet isograd from blueschist-facies metapelites of the Ile de Groix, Armorican Massif, France. Journal of Petrology, 43(3), 485-510. https://doi.org/10.1093/petrology/43.3.485

Bosse, V., Féraud, G., Ballèvre, M., Peucat, J.-J., \& Corsini, M. (2005). Rb-Sr and 40Ar/39Ar ages in blueschists from the Ile de Groix (Armorican Massif, France): Implications for closure mechanisms in isotopic systems. Chemical Geology, 220(1-2), 21-45. https://doi.org/10.1016/j.chemgeo.2005.02.019

Bossière, G. (1988). Evolutions chimico-minéralogiques du grenat et de la muscovite au voisinage de l'isograde biotite-staurotide dans un métamorphisme prograde de type barrovien: un exemple en Vendée littorale (Massif Armoricain). Comptes Rendus de l'Académie Des Sciences. Série 2, Mécanique, Physique, Chimie, Sciences de l'univers, Sciences de La Terre, 306(2), 135-140.

Bouchot, V., Ledru, P., Lerouge, C., Lescuyer, J.-L. L., \& Milesi, J.-P. P. (2005). Late Variscan mineralizing systems related to orogenic processes: The French Massif Central. Ore Geology Reviews, 27(1-4), 169-197. https://doi.org/10.1016/j.oregeorev.2005.07.017

Boulvais, P., Poujol, M., Branquet, Y., Cogné, N., Tartèse, R., Duretz, T., Ballouard, C., Dusséaux, C., \& Gébelin, A. (2019). The uranium metallogeny in the South Armorican detachment zones, Variscan belt, France: geology, tracing (in space and time), numerical modelling. 15th Biennial Meeting of the Society for Geology Applied to Mineral Deposits.

Brown, M., \& Dallmeyer, R. D. R. (1996). Rapid Variscan exhumation and the role of magma in core complex formation: southern Brittany metamorphic belt, France. Journal of Metamorphic Geology, 14(3), 361-379. https://doi.org/10.1111/j.15251314.1996.00361.x

Cagnard, F., Gapais, D., Brun, J. P., Gumiaux, C., \& Van den Driessche, J. (2004). Late pervasive crustal-scale extension in the south Armorican Hercynian belt (Vendée, France). Journal of Structural Geology, 26(3), 435-449. https://doi.org/10.1016/j.jsg.2003.08.006

Capdevila, R. (2012). Les granites varisques du Massif Armoricain. Bulletin de La Société Géologique et Minéralogique de Bretagne, D(7), 1-52. https://hal-insu.archivesouvertes.fr/insu-00744843

Caroff, M., Le Gall, B., Authemayou, C., Bussien Grosjean, D., Labry, C., \& Guillong, M. (2016). Relations between basalts and adakitic-felsic intrusive bodies in a soft-substrate environment: the South Ouessant Visean basin in the Variscan belt, Armorican Massif, France. Canadian Journal of Earth Sciences, 53(4), 441-456. https://doi.org/10.1139/cjes-2015-0230

Castonguay, S., Ruffet, G., \& Tremblay, A. (2007). Dating polyphase deformation across lowgrade metamorphic belts: An example based on 40Ar/39Ar muscovite age constraints from the southern Quebec Appalachians, Canada. Geological Society of America Bulletin, 

119(7-8), 978-992. https://doi.org/10.1130/B26046.1

Cheilletz, A., Ruffet, G., Marignac, C., Kolli, O., Gasquet, D., Féraud, G., \& Bouillin, J. . (1999). 40Ar/39Ar dating of shear zones in the Variscan basement of Greater Kabylia (Algeria). Evidence of an Eo-Alpine event at $128 \mathrm{Ma}$ (Hauterivian-Barremian boundary): geodynamic consequences. Tectonophysics, 306(1), 97-116. https://doi.org/10.1016/S0040-1951(99)00047-5

Cherniak, D. ., Watson, E. B., Grove, M., \& Harrison, T. M. (2004). Pb diffusion in monazite: a combined RBS/SIMS study. Geochimica et Cosmochimica Acta, 68(4), 829-840. https://doi.org/10.1016/j.gca.2003.07.012

Chew, D. M., \& Spikings, R. A. (2015). Geochronology and Thermochronology Using Apatite: Time and Temperature, Lower Crust to Surface. Elements, 11(3), 189-194. https://doi.org/10.2113/gselements.11.3.189

Craw, D. (2002). Geochemistry of late metamorphic hydrothermal alteration and graphitisation of host rock, Macraes gold mine, Otago Schist, New Zealand. Chemical Geology, 191(4), 257-275. https://doi.org/10.1016/S0009-2541(02)00139-0

Cuney, M., Alexandrov, P., Le Carlier de Veslud, C., Cheilletz, A., Raimbault, L., Ruffet, G., \& Scaillet, S. (2002). The timing of W-Sn-rare metals mineral deposit formation in the Western Variscan chain in their orogenic setting: the case of the Limousin area (Massif Central, France). Geological Society, London, Special Publications, 204(1), 213-228. https://doi.org/10.1144/GSL.SP.2002.204.01.13

Cuney, Michel. (2014). Felsic magmatism and uranium deposits. Bulletin de La Societe Geologique de France, 185(2), 75-92. https://doi.org/10.2113/gssgfbull.185.2.75

Dusséaux, C. (2019). Topographic reconstructions of the Variscan belt of Western Europe through the study of fossil hydrothermal systems. Ph.D. thesis. University of Plymouth, UK.

Dusséaux, C., Gébelin, A., Boulvais, P., Gardien, V., Grimes, S., \& Mulch, A. (2019a). Meteoric fluid-rock interaction in Variscan shear zones. Terra Nova, 31(4), ter.12392. https://doi.org/10.1111/ter.12392

Dusséaux, C., Gébelin, A., Boulvais, P., Gardien, V., Grimes, S., \& Mulch, A. (2019b). Meteoric fluid- rock interaction in Variscan shear zones. Terra Nova, 31(4), ter.12392. https://doi.org/10.1111/ter.12392

Dusséaux, C., Gébelin, A., Ruffet, G., \& Mulch, A. (2021). Late Carboniferous paleoelevation of the Variscan Belt of Western Europe. Earth and Planetary Science Letters, 569, 117064. https://doi.org/10.1016/j.epsl.2021.117064

El Korh, A., Schmidt, S. T., Vennemann, T., \& Ulianov, A. (2011). Trace Element and OIsotope Composition of Polyphase Metamorphic Veins of the Ile de Groix (Armorican Massif, France). In L. F. Dobrzhinetskaya, S. W. Faryad, S. Wallis, \& S. Cuthbert (Eds.), Ultrahigh-Pressure Metamorphism (pp. 243-291). Elsevier. https://doi.org/10.1016/B978-0-12-385144-4.00008-4

Famin, V., Philippot, P., Jolivet, L., \& Agard, P. (2004). Evolution of hydrothermal regime along a crustal shear zone, Tinos Island, Greece. Tectonics, 23(5). https://doi.org/10.1029/2003TC001509

Field, C. W., \& Fifarek, R. H. (1985). Light stable-isotope systematics in the epithermal environment. In B. R. Berger \& P. M. Bethke (Eds.), Geology and Geochemistry of Epithermal Systems (Rev. Econ., pp. 99-128). Soc. of Econ. Geol. https://doi.org/10.5382/Rev.02.06

Foster, G., Parrish, R. R., Horstwood, M. S. A., Chenery, S., Pyle, J., \& Gibson, H. D. (2004). The generation of prograde $\mathrm{P}-\mathrm{T}-\mathrm{t}$ points and paths; a textural, compositional, and chronological study of metamorphic monazite. Earth and Planetary Science Letters, 228(1-2), 125-142. https://doi.org/10.1016/j.epsl.2004.09.024 
Gapais, D., \& Boundi, A. L. B. (2014). Pegmatite mylonites: origin and significance. Geological Society, London, Special Publications, 409, SP409.7. https://doi.org/10.1144/SP409.7

Gapais, D., Brun, J.-P., Gumiaux, C., Cagnard, F., Ruffet, G., \& Le Carlier De Veslud, C. (2015). Extensional tectonics in the Hercynian Armorican belt (France). An overview. Bulletin de La Société Géologique de France, 186(2-3), 117-129. https://doi.org/10.2113/gssgfbull.186.2-3.117 Den Driessche, J. (1993). La zone de cisaillement de Quiberon : témoin d'extension de la chaîne varisque en Bretagne méridionale au Carbonifère. Comptes Rendus de l'Académie Des Sciences - Series II - Mécanique, Physique, Chimie, Sciences de l'univers, Sciences de La Terre, 316(January 1993), 1123-1129.

Gardés, E., Jaoul, O., Montel, J.-M., Seydoux-Guillaume, A.-M., \& Wirth, R. (2006). Pb diffusion in monazite: An experimental study of interdiffusion. Geochimica et Cosmochimica Acta, 70(9), 2325-2336. https://doi.org/10.1016/j.gca.2006.01.018

Gardés, E., Montel, J.-M., Seydoux-Guillaume, A.-M., \& Wirth, R. (2007). Pb diffusion in monazite: New constraints from the experimental study of interdiffusion. Geochimica et Cosmochimica Acta, 71(16), 4036-4043. https://doi.org/10.1016/j.gca.2007.06.036

Gébelin, A., Jessup, M. J., Teyssier, C., Cosca, M. A., Law, R. D., Brunel, M., \& Mulch, A. (2017). Infiltration of meteoric water in the South Tibetan Detachment (Mount Everest, Himalaya): When and why? Tectonics, 36(4), 690-713. https://doi.org/10.1002/2016TC004399

Gébelin, A., Martelet, G., Chen, Y., Brunel, M., \& Faure, M. (2006). Structure of late Variscan Millevaches leucogranite massif in the French Massif Central: AMS and gravity modelling results. Journal of Structural Geology, 28(1), 148-169. https://doi.org/10.1016/j.jsg.2005.05.021

Gébelin, A., Mulch, A., Teyssier, C., Heizler, M., Vennemann, T., \& Seaton, N. C. A. (2011). Oligo-Miocene extensional tectonics and fluid flow across the Northern Snake Range detachment system, Nevada. Tectonics, 30(5). https://doi.org/10.1029/2010TC002797

Gébelin, A., Mulch, A., Teyssier, C., Jessup, M. J., Law, R. D., \& Brunel, M. (2013). The Miocene elevation of Mount Everest. Geology, 41(7), 799-802. https://doi.org/10.1130/G34331.1

Gébelin, A., Mulch, A., Teyssier, C., Page Chamberlain, C., \& Heizler, M. (2012). Coupled basin-detachment systems as paleoaltimetry archives of the western North American Cordillera. Earth and Planetary Science Letters, 335-336, 36-47. https://doi.org/10.1016/j.eps1.2012.04.029

Gébelin, A., Roger, F., \& Brunel, M. (2009). Syntectonic crustal melting and high-grade metamorphism in a transpressional regime, Variscan Massif Central, France. Tectonophysics, 477(3-4), 229-243. https://doi.org/10.1016/j.tecto.2009.03.022

Gébelin, A., Teyssier, C., Heizler, M. T., \& Mulch, A. (2015). Meteoric water circulation in a rolling-hinge detachment system (northern Snake Range core complex, Nevada). Bulletin of the Geological Society of America, 127(1-2), 149-161. https://doi.org/10.1130/B31063.1

Gottardi, R., Teyssier, C., Mulch, A., Vennemann, T. W., \& Wells, M. L. (2011). Preservation of an extreme transient geotherm in the Raft River detachment shear zone. Geology, 39(8), 759-762. https://doi.org/10.1130/G31834.1

Gottardi, Raphaël, Kao, P.-H., Saar, M. O., \& Teyssier, C. (2013). Effects of permeability fields on fluid, heat, and oxygen isotope transport in extensional detachment systems. Geochemistry, Geophysics, https://doi.org/10.1002/ggge.20100

Geosystems, 14(5), $1493-1522$. 
932

933

934

935

936

937

938

939

940

941

942

943

944

945

946

947

948

949

950

951

952

953

954

955

956

957

958

959

960

961

962

963

964

965

966

967

968

969

970

971

972

973

974

975

976

977

978

979

980

981
Gottardi, Raphaël, Schaper, M. C., Barnes, J. D., \& Heizler, M. T. (2018). Fluid-Rock Interaction and Strain Localization in the Picacho Mountains Detachment Shear Zone, Arizona, USA. Tectonics, 37(9), 3244-3260. https://doi.org/10.1029/2017TC004835

Goujou, J.-C. (1992). Analyse pétro-structurale d'un avant-pays métamorphique: influence du plutonisme tardi-orogénique Varisque sur l'encaissant épi à mésozonal de Vendée. Université de Montpellier 2, Montpellier, France.

Grambling, T. A., Jessup, M. J., Newell, D. L., Methner, K., Mulch, A., Hughes, C. A., \& Shaw, C. A. (2022). Miocene to modern hydrothermal circulation and high topography during synconvergent extension in the Cordillera Blanca, Peru. Geology, 50(1), 106-110. https://doi.org/10.1130/G49263.1

Grand'Homme, A., Janots, E., Seydoux-Guillaume, A.-M., Guillaume, D., Bosse, V., \& Magnin, V. (2016). Partial resetting of the U-Th-Pb systems in experimentally altered monazite: Nanoscale evidence of incomplete replacement. Geology, 44(6), 431-434. https://doi.org/10.1130/G37770.1

Harlaux, M., Romer, R. L., Mercadier, J., Morlot, C., Marignac, C., \& Cuney, M. (2018). 40 Ma of hydrothermal $\mathrm{W}$ mineralization during the Variscan orogenic evolution of the French Massif Central revealed by U-Pb dating of wolframite. Mineralium Deposita, 53(1), 21-51. https://doi.org/10.1007/s00126-017-0721-0

Harrison, T. M., Célérier, J., Aikman, A. B., Hermann, J., \& Heizler, M. T. (2009). Diffusion of 40Ar in muscovite. Geochimica et Cosmochimica Acta, 73(4), 1039-1051. https://doi.org/10.1016/j.gca.2008.09.038

Hetherington, C. J., Backus, E. L., McFarlane, C. R. M., Fisher, C. M., \& Pearson, D. G. (2017). Origins of Textural, Compositional, and Isotopic Complexity in Monazite and Its Petrochronological Analysis (pp. 63-90). https://doi.org/10.1002/9781119227250.ch3

Hirth, G., \& Tullis, J. (1992). Dislocation creep regimes in quartz aggregates. Journal of Structural Geology, 14(2), 145-159. https://doi.org/10.1016/0191-8141(92)90053-Y

Hunter, N. J. R., Hasalová, P., Weinberg, R. F., \& Wilson, C. J. L. (2016). Fabric controls on strain accommodation in naturally deformed mylonites: The influence of interconnected micaceous layers. Journal of Structural Geology, 83, 180-193. https://doi.org/10.1016/j.jsg.2015.12.005

Jegouzo, P. (1980). The South Armorican Shear Zone. Journal of Structural Geology, 2(1), $39-57$.

Jolivet, J., Bienfait, G., Vigneresse, J. L., \& Cuney, M. (1989). Heat flow and heat production in Brittany (Western France). Tectonophysics, 159(1-2), 61-72. https://doi.org/10.1016/0040-1951(89)90170-4

Jones, K. A., \& Brown, M. (1990). High-temperature 'clockwise' P-T paths and melting in the development of regional migmatites: an example from southern Brittany, France. Journal of Metamorphic Geology, 8, 551-578.

Kelley, S. (2002). Excess argon in K-Ar and Ar-Ar geochronology. Chemical Geology, 188(12), 1-22. https://doi.org/10.1016/S0009-2541(02)00064-5

Kilian, R., \& Heilbronner, R. (2017). Analysis of crystallographic preferred orientations of experimentally deformed Black Hills Quartzite. Solid Earth, 8(5), 1095-1117. https://doi.org/10.5194/se-8-1095-2017

Kotzer, T. ., Kyser, T. ., King, R. ., \& Kerrich, R. (1993). An empirical oxygen- and hydrogenisotope geothermometer for quartz-tourmaline and tourmaline-water. Geochimica et Cosmochimica Acta, 57(14), 3421-3426. https://doi.org/10.1016/0016-7037(93)90548-B

Krohe, \& Wawrzenitz. (2000). Domainal variations of U-Pb monazite ages and Rb-Sr wholerock dates in polymetamorphic paragneisses (KTB Drill Core, Germany): influence of strain and deformation mechanisms on isotope systems. Journal of Metamorphic Geology, 18(3), 271-291. https://doi.org/10.1046/j.1525-1314.2000.00255.x 
982

983

984

985

986

987

988

989

990

991

992

993

994

995

996

997

998

999

1000

1001

1002

1003

1004

1005

1006

1007

1008

1009

1010

1011

1012

1013

1014

1015

1016

1017

1018

1019

1020

1021

1022

1023

1024

1025

1026

1027

1028

1029

1030

1031
Le Hebel, F., Fourcade, S., Boiron, M. C., Cathelineau, M., Capdevila, R., \& Gapais, D. (2007). Fluid history during deep burial and exhumation of oil-bearing volcanics, Hercynian Belt of southern Brittany, France. American Journal of Science, 307(9), 1096-1125. https://doi.org/10.2475/09.2007.03

Le Hebel, F., Vidal, O., Kienast, J., \& Gapais, D. (2002). Les «Porphyrö̈des » de Bretagne méridionale: une unité de HP-BT dans la chaîne hercynienne. Comptes Rendus Geoscience, 334(3), 205-211. https://doi.org/10.1016/S1631-0713(02)01746-7

Lemarchand, J., Boulvais, P., Gaboriau, M., Boiron, M.-C., Tartese, R., Cokkinos, M., Bonnet, S., \& Jegouzo, P. (2012). Giant quartz vein formation and high-elevation meteoric fluid infiltration into the South Armorican Shear Zone: geological, fluid inclusion and stable isotope evidence. Journal of the Geological Society, 169(1), 17-27. https://doi.org/10.1144/0016-76492010-186

Lister, G. S., \& Snoke, A. W. (1984). S-C Mylonites. Journal of Structural Geology, 6(6), 617638. https://doi.org/10.1016/0191-8141(84)90001-4

López-Moro, F. J., López-Plaza, M., \& Romer, R. L. (2012). Generation and emplacement of shear-related highly mobile crustal melts: the synkinematic leucogranites from the Variscan Tormes Dome, Western Spain. International Journal of Earth Sciences, 101(5), 1273-1298. https://doi.org/10.1007/s00531-011-0728-1

Martín Crespo, T., Delgado, A., Vindel Catena, E., López García, J. A., \& Fabre, C. (2002). The latest Post-Variscan fluids in the Spanish Central System: Evidence from fluid inclusion and stable isotope data. Marine and Petroleum Geology, 19(3), 323-337. https://doi.org/10.1016/S0264-8172(02)00020-X

McCaig, A. M. (1988). Deep fluid circulation in fault zones. Geology, 16(10), 867. https://doi.org/10.1130/0091-7613(1988)016<0867:DFCIFZ>2.3.CO;2

Methner, K., Mulch, A., Teyssier, C., Wells, M. L., Cosca, M. A., Gottardi, R., Gébelin, A., \& Chamberlain, C. P. (2015). Eocene and Miocene extension, meteoric fluid infiltration, and core complex formation in the Great Basin (Raft River Mountains, Utah). Tectonics, 34(4), 680-693. https://doi.org/10.1002/2014TC003766

Miller, C. F., Stoddard, E. F., Bradfish, L. J., \& Dollase, W. A. (1981). Composition of plutonic muscovite; genetic implications. The Canadian Mineralogist, 19(1), 25-34.

Morrison, J. (1998). Footwall Refrigeration Along a Detachment Fault: Implications for the Thermal Evolution of Core Complexes. Science, 279(5347), 63-66. https://doi.org/10.1126/science.279.5347.63

Mottram, C. M., Warren, C. J., Regis, D., Roberts, N. M. W., Harris, N. B. W., Argles, T. W., \& Parrish, R. R. (2014). Developing an inverted Barrovian sequence; insights from monazite petrochronology. Earth and Planetary Science Letters, 403, 418-431. https://doi.org/10.1016/j.epsl.2014.07.006

Mulch, A., Graham, S. A., \& Chamberlain, C. P. (2006). Hydrogen Isotopes in Eocene River Gravels and Paleoelevation of the Sierra Nevada. Science, 313(5783), 87-89. https://doi.org/10.1126/science.1125986

Mulch, A., Teyssier, C., Cosca, M. A., Vanderhaeghe, O., \& Vennemann, T. W. (2004). Reconstructing paleoelevation in eroded orogens. Geology, 32(6), 525. https://doi.org/10.1130/G20394.1

Nesbitt, B. E., \& Muehlenbachs, K. (1995). Geochemical studies of the origins and effects of synorogenic crustal fluids in the southern Omineca Belt of British Columbia, Canada. Geological Society of America Bulletin, 107(9), 1033-1050. https://doi.org/10.1130/0016-7606(1995)107<1033:GSOTOA>2.3.CO;2

Nüchter, J.-A., \& Ellis, S. (2011). Mid-crustal controls on episodic stress-field rotation around major reverse, normal and strike-slip faults. Geological Society, London, Special Publications, 359(1), 187-201. https://doi.org/10.1144/SP359.11 
1032

1033

1034

1035

1036

1037

1038

1039

1040

1041

1042

1043

1044

1045

1046

1047

1048

1049

1050

1051

1052

1053

1054

1055

1056

1057

1058

1059

1060

1061

1062

1063

1064

1065

1066

1067

1068

1069

1070

1071

1072

1073

1074

1075

1076

1077

1078

1079

1080

1081

Padovano, M., Dörr, W., Elter, F. M., \& Gerdes, A. (2014). The East Variscan Shear Zone: Geochronological constraints from the Capo Ferro area (NE Sardinia, Italy). Lithos, 196197, 27-41. https://doi.org/10.1016/j.lithos.2014.01.015

Paquette, J.-L., Ballèvre, M., Peucat, J.-J., \& Cornen, G. (2017). From opening to subduction of an oceanic domain constrained by LA-ICP-MS U-Pb zircon dating (Variscan belt, Southern Armorican Massif, France). Lithos, 294-295, 418-437. https://doi.org/10.1016/j.lithos.2017.10.005

Parrish, R. R. (1990). U-Pb dating of monazite and its application to geological problems. Canadian Journal of Earth Sciences, 27(11), 1431-1450. https://doi.org/10.1139/e90-152

Person, M., Mulch, A., Teyssier, C., \& Gao, Y. (2007). Isotope transport and exchange within metamorphic core complexes. American Journal of Science, 307(3), 555-589. https://doi.org/10.2475/03.2007.01

Peucat, J.-J. (1983). Géochronologie des roches métamorphiques (Rb-Sr et U-Pb): exemples choisis au Groenland, en Laponie, dans le Massif armoricain et en Grande Kabylie. Mémoires de La Société Géologique et Minéralogique de Bretagne, 28, 158pp.

Pitra, P., Ballèvre, M., \& Ruffet, G. (2010). Inverted metamorphic field gradient towards a Variscan suture zone (Champtoceaux Complex, Armorican Massif, France). Journal of Metamorphic Geology, 28(2), 183-208. https://doi.org/10.1111/j.15251314.2009.00862.x

Pitra, Pavel, Poujol, M., Van Den Driessche, J., Bretagne, E., Lotout, C., \& Cogné, N. (2021). Late Variscan (315 Ma) subduction or deceptive zircon REE patterns and $\mathrm{U}-\mathrm{Pb}$ dates from migmatite- hosted eclogites? (Montagne Noire, France). Journal of Metamorphic Geology, jmg.12609. https://doi.org/10.1111/jmg.12609

Pochon, A., Poujol, M., Gloaguen, E., Branquet, Y., Cagnard, F., Gumiaux, C., \& Gapais, D. (2016). U-Pb LA-ICP-MS dating of apatite in mafic rocks: Evidence for a major magmatic event at the Devonian-Carboniferous boundary in the Armorican Massif (France). American Mineralogist, 101(11), 2430-2442. https://doi.org/10.2138/am-2016-5736

Poujol, M., Pitra, P., Van Den Driessche, J., Tartèse, R., Ruffet, G., Paquette, J.-L., \& Poilvet, J.-C. (2017). Two-stage partial melting during the Variscan extensional tectonics (Montagne Noire, France). International Journal of Earth Sciences, 106(2), 477-500. https://doi.org/10.1007/s00531-016-1369-1

Rodríguez-Terente, L. M., Martin-Izard, A., Arias, D., Fuertes-Fuente, M., \& Cepedal, A. (2018). The Salave Mine, a Variscan intrusion-related gold deposit (IRGD) in the NW of Spain: Geological context, hydrothermal alterations and ore features. Journal of Geochemical Exploration, 188(March 2017), 364-389. https://doi.org/10.1016/j.gexplo.2018.02.011

Rolland, Y., Corsini, M., \& Demoux, A. (2009). Metamorphic and structural evolution of the Maures-Tanneron massif (SE Variscan chain): evidence of doming along a transpressional margin. Bulletin de La Societe Geologique de France, 180(3), 217-230. https://doi.org/10.2113/gssgfbull.180.3.217

Ruffet, G., Féraud, G., \& Amouric, M. (1991). Comparison of 40Ar/39Ar conventional and laser dating of biotites from the North Trégor Batholith. Geochimica et Cosmochimica Acta, 55(6), 1675-1688. https://doi.org/10.1016/0016-7037(91)90138-U

Ruffet, Gilles, Féraud, G., Balèvre, M., \& Kiénast, J.-R. (1995). Plateau ages and excess argon in phengites: an 40Ar/39Ar laser probe study of Alpine micas (Sesia Zone, Western Alps, northern Italy). Chemical Geology, 121(1-4), 327-343. https://doi.org/10.1016/00092541(94)00132-R

Seydoux-Guillaume, A.-M., Montel, J.-M., Bingen, B., Bosse, V., de Parseval, P., Paquette, J.L., Janots, E., \& Wirth, R. (2012). Low-temperature alteration of monazite: Fluid mediated coupled dissolution-precipitation, irradiation damage, and disturbance of the U- 
1082

1083

1084

1085

1086

1087

1088

1089

1090

1091

1092

1093

1094

1095

1096

1097

1098

1099

1100

1101

1102

1103

1104

1105

1106

1107

1108

1109

1110

1111

1112

1113

1114

1115

1116

1117

1118

1119

1120

1121

1122

1123

1124

1125

1126

1127

1128

1129

1130

1131

$\mathrm{Pb}$ and $\mathrm{Th}-\mathrm{Pb}$ chronometers. Chemical Geology, 330-331, 140-158. https://doi.org/10.1016/j.chemgeo.2012.07.031

Sibson, R. H. (1981). Controls on low-stress hydro-fracture dilatancy in thrust, wrench and normal fault terrains. Nature, 289(5799), 665-667. https://doi.org/10.1038/289665a0

Stipp, M., Stünitz, H., Heilbronner, R., \& Schmid, S. M. (2002). The eastern Tonale fault zone: a 'natural laboratory' for crystal plastic deformation of quartz over a temperature range from 250 to $700^{\circ} \mathrm{C}$. Journal of Structural Geology, 24(12), 1861-1884. https://doi.org/10.1016/S0191-8141(02)00035-4

Stöckhert, B., Manfred, R. B., Kleinschrodt, R., Hurford, A. J., \& Wirth, R. (1999). Thermochronometry and microstructures of quartz - a comparison with experimental flow laws and predictions on the temperature of the brittle-plastic transition. Journal of Structural Geology, 21, 351-369. https://doi.org/10.1016/S0191-8141(98)00114-X

Sutherland, R., Townend, J., Toy, V., Upton, P., Coussens, J., Allen, M., Baratin, L.-M., Barth, N., Becroft, L., Boese, C., Boles, A., Boulton, C., Broderick, N. G. R., Janku-Capova, L., Carpenter, B. M., Célérier, B., Chamberlain, C., Cooper, A., Coutts, A., ... Zimmer, M. (2017). Extreme hydrothermal conditions at an active plate-bounding fault. Nature, 546(7656), 137-140. https://doi.org/10.1038/nature22355

Suzuoki, T., \& Epstein, S. (1976). Hydrogen isotope fractionation between OH-bearing minerals and water. Geochimica et Cosmochimica Acta, 40(10), 1229-1240. https://doi.org/10.1016/0016-7037(76)90158-7

Tartèse, R., \& Boulvais, P. (2010). Differentiation of peraluminous leucogranites "en route" to the surface. Lithos, 114(3-4), 353-368. https://doi.org/10.1016/j.lithos.2009.09.011

Tartèse, R., Boulvais, P., Poujol, M., Chevalier, T., Paquette, J., Ireland, T. R., \& Deloule, E. (2012). Mylonites of the South Armorican Shear Zone : Insights for crustal-scale fluid flow and water - rock interaction processes. Journal of Geodynamics, 56-57, 86-107. https://doi.org/10.1016/j.jog.2011.05.003

Tartèse, R., Boulvais, P., Poujol, M., Gloaguen, E., \& Cuney, M. (2013). Uranium mobilization from the variscan questembert syntectonic granite during fluid-rock interaction at depth. Economic Geology, 108(2), 379-386. https://doi.org/10.2113/econgeo.108.2.379

Tartèse, R., Boulvais, P., Poujol, M., \& Vigneresse, J. L. (2011a). Granite petrogenesis revealed by combined gravimetric and radiometric imaging. Tectonophysics, 501(1-4), 98-103. https://doi.org/10.1016/j.tecto.2011.02.003

Tartèse, R., Poujol, M., Ruffet, G., Boulvais, P., Yamato, P., \& Košler, J. (2011b). New U-Pb zircon and 40Ar/39Ar muscovite age constraints on the emplacement of the Lizio syntectonic granite (Armorican Massif, France). Comptes Rendus Geoscience, 343(7), 443453. https://doi.org/10.1016/j.crte.2011.07.005

Tartèse, R., Ruffet, G., Poujol, M., Boulvais, P., \& Ireland, T. R. (2011c). Simultaneous resetting of the muscovite $\mathrm{K}-\mathrm{Ar}$ and monazite $\mathrm{U}-\mathrm{Pb}$ geochronometers: a story of fluids. Terra Nova, 23(6), 390-398. https://doi.org/10.1111/j.1365-3121.2011.01024.x

ten Grotenhuis, S. M., Trouw, R. A. J., \& Passchier, C. W. (2003). Evolution of mica fish in mylonitic rocks. Tectonophysics, 372(1-2), 1-21. https://doi.org/10.1016/S00401951(03)00231-2

Teyssier, C., \& Whitney, D. L. (2002). Gneiss domes and orogeny. Geology, 30(12), 1139. https://doi.org/10.1130/0091-7613(2002)030<1139:GDAO>2.0.CO;2

Thinon, I., Menier, D., Guennoc, P., \& Proust, J.-N. (2008). Geological map of the continental margin (scale 1/250,000), sheet Lorient (South Brittany). BRGM.

Tirel, C., Brun, J.-P., \& Burov, E. (2008). Dynamics and structural development of metamorphic core complexes. Journal of Geophysical Research, 113(B4), B04403. https://doi.org/10.1029/2005JB003694

Tremblay, A., Ruffet, G., \& Bédard, J. H. (2011). Obduction of Tethyan-type ophiolites-A 
case-study from the Thetford-Mines ophiolitic Complex, Quebec Appalachians, Canada. Lithos, 125(1-2), 10-26. https://doi.org/10.1016/j.lithos.2011.01.003

Triboulet, C. L., \& Audren, C. (1988). Controls on P-T-t deformation path from amphibole zonation during progressive metamorphism of basic rocks (estuary of the River Vilaine, South Brittany, France). Journal of Metamorphic Geology, 6(2), 117-133. https://doi.org/10.1111/j.1525-1314.1988.tb00412.x

Turpin, L., Leroy, J. L., \& Sheppard, S. M. F. (1990). Isotopic systematics ( O , H , C , Sr , Nd ) of superimposed barren and U-bearing hydrothermal systems in a Hercynian granite, Massif Central , France. Chemical Geology, 88, 85-98. https://doi.org/10.1016/00092541(90)90105-g

Turrillot, P. (2010). Fusion crustale et évolution tardi-orogénique du Domaine Sud Armoricain. Ph.D. thesis, Institut des Sciences de la Terre d'Orléans.

Turrillot, P., Augier, R., \& Faure, M. (2009). The top-to-the-southeast Sarzeau shear zone and its place in the late-orogenic extensional tectonics of southern Armorica. Bulletin de La Societe Geologique de France, 180(3), 247-261. https://doi.org/10.2113/gssgfbull.180.3.247

Turrillot, P., Augier, R., Monié, P., Faure, M., Monié, P., \& Faure, M. (2011). Late orogenic exhumation of the Variscan high-grade units (South Armorican Domain, western France), combined structural and $40 \mathrm{Ar} / 39$ Ar constraints. Tectonics, 30 (TC5007, 1-27. https://doi.org/10.1029/2010TC002788

Upton, Phædra, Koons, P. O., \& Chamberlain, C. P. (1995). Penetration of deformation- driven meteoric water into ductile rocks: Isotopic and model observations from the Southern Alps, New Zealand. New Zealand Journal of Geology and Geophysics, 38(4), 535-543. https://doi.org/10.1080/00288306.1995.9514680

Upton, Phaedra, \& Sutherland, R. (2014). High permeability and low temperature correlates with proximity to brittle failure within mountains at an active tectonic boundary, Manapouri tunnel, Fiordland, New Zealand. Earth and Planetary Science Letters, 389, 176-187. https://doi.org/10.1016/j.eps1.2013.12.032

Vanderhaeghe, O., Laurent, O., Gardien, V., Moyen, J., Gébelin, A., Chelle-Michou, C., Couzinié, S., Villaros, A., \& Bellanger, M. (2020). Flow of partially molten crust controlling construction, growth and collapse of the Variscan orogenic belt. BSGF - Earth Sciences Bulletin, 191, 25. https://doi.org/10.1051/bsgf/2020013

Vigneresse, J. L., Cuney, M., Jolivet, J., \& Bienfait, G. (1989). Selective heat-producing element enrichment in a crustal segment of the mid-European Variscan chain. Tectonophysics, 159(1-2), 47-60. https://doi.org/10.1016/0040-1951(89)90169-8

Wawrzenitz, N., Krohe, A., Baziotis, I., Mposkos, E., Kylander-Clark, A. R. C., \& Romer, R. L. (2015). LASS U-Th-Pb monazite and rutile geochronology of felsic high-pressure granulites (Rhodope, $\mathrm{N}$ Greece): Effects of fluid, deformation and metamorphic reactions in local subsystems. Lithos, 232, 266-285. https://doi.org/10.1016/j.lithos.2015.06.029

Whitney, D. L., Roger, F., Teyssier, C., Rey, P. F., \& Respaut, J. P. (2015). Syn-collapse eclogite metamorphism and exhumation of deep crust in a migmatite dome: The P-T-t record of the youngest Variscan eclogite (Montagne Noire, French Massif Central). Earth and Planetary Science Letters, 430, 224-234. https://doi.org/10.1016/j.eps1.2015.08.026

Whitney, D. L., Teyssier, C., Rey, P., \& Buck, W. R. (2013). Continental and oceanic core complexes. Geological Society of America Bulletin, 125(3-4), 273-298. https://doi.org/10.1130/B30754.1

Wu, C.-M., \& Chen, H.-X. (2015). Calibration of a Ti-in-muscovite geothermometer for ilmenite- and Al2SiO5-bearing metapelites. Lithos, 212-215(December), 122-127. https://doi.org/10.1016/j.lithos.2014.11.008 


\title{
Timing and duration of meteoric water infiltration in the Quiberon detachment zone (Armorican Massif, Variscan belt, France)
}

\author{
Camille Dusséaux $^{1 *}$, Aude Gébelin ${ }^{1}$, Philippe Boulvais ${ }^{2}$, Gilles Ruffet ${ }^{2}$, Marc Poujol' ${ }^{2}$, Nathan \\ Cogné2 $^{2}$ Yannick Branquet ${ }^{2,3}$, Catherine Mottram4, Fabrice Barou ${ }^{5}$, Andreas Mulch ${ }^{6,7}$
}

Table 1. GPS locations, hydrogen isotope composition $(\delta \mathrm{D})$ of muscovite $(\mathrm{Ms})$ and tourmaline $(\mathrm{To})$ from leucogranite, micaschist, quartz vein and pegmatite found in the mylonitic footwall of Quiberon

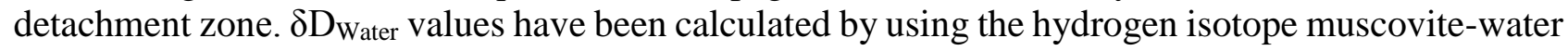
and tourmaline-water fractionation factors $(\alpha)$ of Suzuoki and Epstein [1976] and Kotzer et al. [1993], respectively, and using temperatures indicated by the Ti-in-Ms thermometer $\left(546\right.$ and $569 \pm 42^{\circ} \mathrm{C}$ for QUIB03 and QUIB01 respectively, and the average temperature of $558 \pm 42^{\circ} \mathrm{C}$ for the other samples). Calculated $\delta \mathrm{D}_{\text {water }}$ values have propagated uncertainties of $\pm 5.2 \%$, considering the precision of isotopic analyses $\left(\delta \mathrm{D}_{\text {hydrous silicate }} \pm 2 \%\right.$ ) and the uncertainties linked to the temperature of recrystallization $\left(\mathrm{T} \pm 42^{\circ} \mathrm{C}\right.$ results in $\delta \mathrm{D}_{\text {Water }}$ uncertainties of $\pm 5 \%$ ). Structural distances of samples below the estimated detachment interface are indicated in $\mathrm{m}$ (see text for explanation). 


\begin{tabular}{|c|c|c|c|c|c|c|c|c|c|c|c|c|c|c|c|}
\hline \multirow[t]{2}{*}{ Name } & \multirow[t]{2}{*}{ Rock type } & \multirow{2}{*}{ 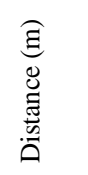 } & \multirow{2}{*}{$\begin{array}{l}\delta \mathrm{D}_{\text {Muscovite }} \\
(\% \mathrm{o}) \pm 2 \% \mathrm{o} \\
250 \mu \mathrm{m}<\mathrm{f}\end{array}$} & \multirow{2}{*}{$\begin{array}{l}\delta \mathrm{D}_{\text {Tourmaline }} \\
(\% \mathrm{o}) \pm 2 \% \mathrm{o} \\
250 \mu \mathrm{m}<\mathrm{f}\end{array}$} & \multirow{2}{*}{$\begin{array}{c}\delta \mathrm{D}_{\mathrm{Ms}} \\
- \\
\delta \mathrm{D}_{\mathrm{To}} \\
(\% 0)\end{array}$} & \multirow{2}{*}{$\begin{array}{l}\text { Temperature } \\
\left({ }^{\circ} \mathrm{C}\right) \text { based } \\
\text { on Ti-in-Ms } \\
\text { thermometry }\end{array}$} & \multirow{2}{*}{$\begin{array}{c} \pm \\
\left({ }^{\circ} \mathrm{C}\right)\end{array}$} & \multicolumn{3}{|c|}{$\begin{array}{c}\delta \mathrm{D}_{\text {Water }}(\%) \text { based on the } \delta \mathrm{D}_{\text {Muscovite }} \\
\text { values and the Ti-in-Ms } \\
\text { thermometry }\end{array}$} & \multicolumn{3}{|c|}{$\begin{array}{l}\delta \mathrm{D}_{\text {Water }}(\%) \text { based on the } \delta \mathrm{D}_{\text {Tourmaline }} \\
\text { values and the Ti-in-Ms thermometry }\end{array}$} & \multicolumn{2}{|c|}{ Location } \\
\hline & & & & & & & & $\delta \mathrm{D}_{\text {Water }}(\%)$ & - & + & $\delta \mathrm{D}_{\text {Water }}(\%)$ & - & + & Latitude (DD) & Longitude (DD) \\
\hline $\begin{array}{c}\text { QUIB } \\
07\end{array}$ & Micaschist & 200 & -76 & & & 558 & 42 & -63 & -3 & 4 & & & & $47^{\circ} 30^{\prime} 21.85^{\prime \prime} \mathrm{N}$ & $03^{\circ} 09^{\prime} 00.54^{\prime \prime} \mathrm{W}$ \\
\hline $\begin{array}{l}\text { QUIB } \\
08\end{array}$ & Quarz vein & 250 & -76 & -81 & 5 & 558 & 42 & -63 & -3 & 4 & -70 & -4 & 4 & $47^{\circ} 30^{\prime} 26.2^{\prime \prime} \mathrm{N}$ & $03^{\circ} 08^{\prime} 58.6^{\prime \prime} \mathrm{W}$ \\
\hline $\begin{array}{l}\text { QUIB } \\
09\end{array}$ & Quarz vein & 255 & -76 & & & 558 & 42 & -63 & -3 & 4 & & & & $47^{\circ} 30^{\prime} 26.1 " \mathrm{~N}$ & $03^{\circ} 08^{\prime} 58.6^{\prime \prime} \mathrm{W}$ \\
\hline $\begin{array}{c}\text { QUIB } \\
01\end{array}$ & $\begin{array}{l}\text { Mylonitic } \\
\text { leucogranite }\end{array}$ & 300 & -85 & -87 & 2 & 569 & 42 & -73 & -2 & 4 & -77 & -3 & 5 & $47^{\circ} 29^{\prime} 0.85^{\prime \prime} \mathrm{N}$ & $3^{\circ} 8^{\prime} 42.68 " \mathrm{~W}$ \\
\hline $\begin{array}{l}\text { QUIB } \\
02\end{array}$ & $\begin{array}{c}\text { Mylonitic } \\
\text { leucogranite }\end{array}$ & 305 & -79 & & & 558 & 42 & -66 & -3 & 4 & & & & $47^{\circ} 29^{\prime} 0.85^{\prime \prime} \mathrm{N}$ & $3^{\circ} 8^{\prime} 42.68 " \mathrm{~W}$ \\
\hline $\begin{array}{l}\text { QUIB } \\
06\end{array}$ & $\begin{array}{l}\text { Ultramylonitic } \\
\text { pegmatite }\end{array}$ & 320 & -75 & & & 558 & 42 & -62 & -3 & 4 & & & & $47^{\circ} 29^{\prime} 0.85^{\prime \prime} \mathrm{N}$ & $3^{\circ} 8^{\prime} 42.68 " \mathrm{~W}$ \\
\hline $\begin{array}{l}\text { QUIB } \\
04\end{array}$ & $\begin{array}{l}\text { Ultramylonitic } \\
\text { pegmatite }\end{array}$ & 321 & -64 & & & 558 & 42 & -51 & -3 & 4 & & & & $47^{\circ} 29^{\prime} 0.85^{\prime \prime} \mathrm{N}$ & $3^{\circ} 8^{\prime} 42.68 " \mathrm{~W}$ \\
\hline $\begin{array}{l}\text { QUIB } \\
05\end{array}$ & $\begin{array}{l}\text { Ultramylonitic } \\
\text { pegmatite }\end{array}$ & 321.5 & -73 & -80 & 7 & 558 & 42 & -60 & -3 & 4 & -69 & -4 & 4 & $47^{\circ} 29^{\prime} 0.85^{\prime \prime} \mathrm{N}$ & $3^{\circ} 8^{\prime} 42.68 " \mathrm{~W}$ \\
\hline $\begin{array}{c}\text { QUIB } \\
03\end{array}$ & $\begin{array}{c}\text { Mylonitic } \\
\text { leucogranite }\end{array}$ & 322 & -82 & -86 & 4 & 546 & 41 & -68 & -4 & 3 & -74 & -5 & 3 & $47^{\circ} 29^{\prime} 0.85^{\prime \prime} \mathrm{N}$ & $3^{\circ} 8^{\prime} 42.68 " \mathrm{~W}$ \\
\hline $\begin{array}{c}\text { QUIB } \\
16\end{array}$ & Quarz vein & 465 & -79 & & & 558 & 42 & -66 & -3 & 4 & & & & $47^{\circ} 28^{\prime} 54.5^{\prime \prime} \mathrm{N}$ & $03^{\circ} 08^{\prime} 11.0^{\prime \prime} \mathrm{W}$ \\
\hline $\begin{array}{c}\text { QUIB } \\
17\end{array}$ & Quarz vein & 500 & -80 & -85 & 5 & 558 & 42 & -67 & -3 & 4 & -74 & -4 & 4 & $47^{\circ} 28^{\prime} 54.3^{\prime \prime} \mathrm{N}$ & $03^{\circ} 08^{\prime} 07.8^{\prime \prime} \mathrm{W}$ \\
\hline
\end{tabular}

\begin{tabular}{|c|c|c|c|}
\hline Propagated uncertainties & Error & Error $(\%)$ & Propagated error in $\delta \mathrm{D}_{\text {water }}$ \\
\hline Isotopic analysis $(\delta \mathrm{D})$ & $\pm 2 \% 0$ & $\pm 2 \% 0$ & $\pm 5.2 \% 0$ \\
\cline { 1 - 2 } Temperature deduced from Ti-in-Ms geothermometry & $\pm 42^{\circ} \mathrm{C}$ & $\pm 5 \% 0$ & \\
\hline
\end{tabular}




\section{Timing and duration of meteoric water infiltration in the} Quiberon detachment zone (Armorican Massif, Variscan belt, France)

Camille Dusséaux ${ }^{1 *}$, Aude Gébelin ${ }^{1}$, Philippe Boulvais ${ }^{2}$, Gilles Ruffet ${ }^{2}$, Marc Poujol², Nathan Cogné ${ }^{2}$, Yannick Branquet ${ }^{2,3}$, Catherine Mottram ${ }^{4}$, Fabrice Barou ${ }^{5}$, Andreas Mulch $^{6,7}$

\section{Figure 1.}

(A) Map of the southern Armorican domain. SASZ: South Armorican Shear zone; (B) W-E cross-section across the Quiberon detachment and the SASZ; (C) Map of the Quiberon island; (D) W-E cross-section and (E) stereographic projections showing the main structures and rock types found in the Quiberon leucogranite footwall. Modified after Gapais et al $(1993,2015)$, Thinon et al., (2008) and Turillot (2010). Sample coordinates are indicated in Table 1. 


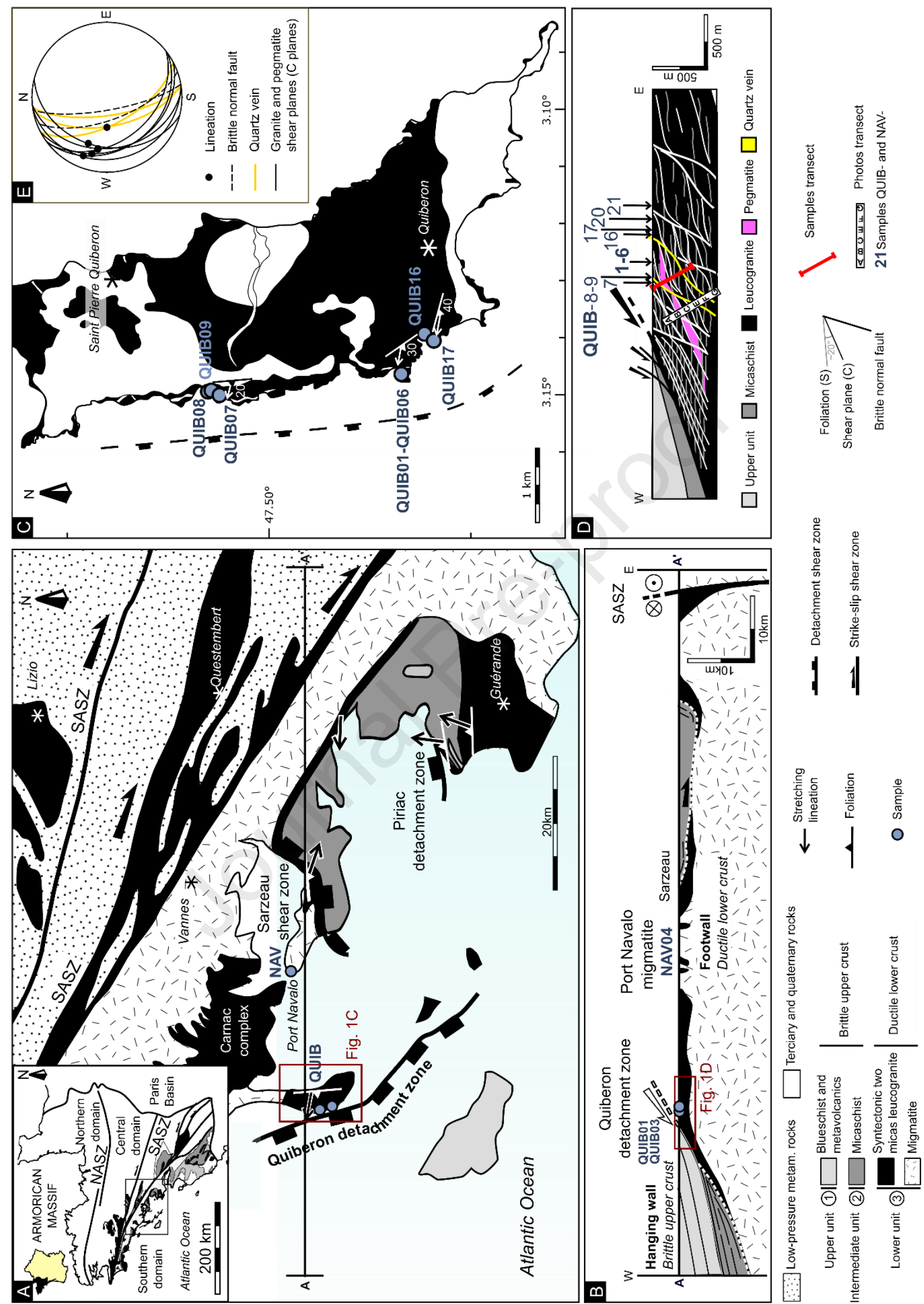



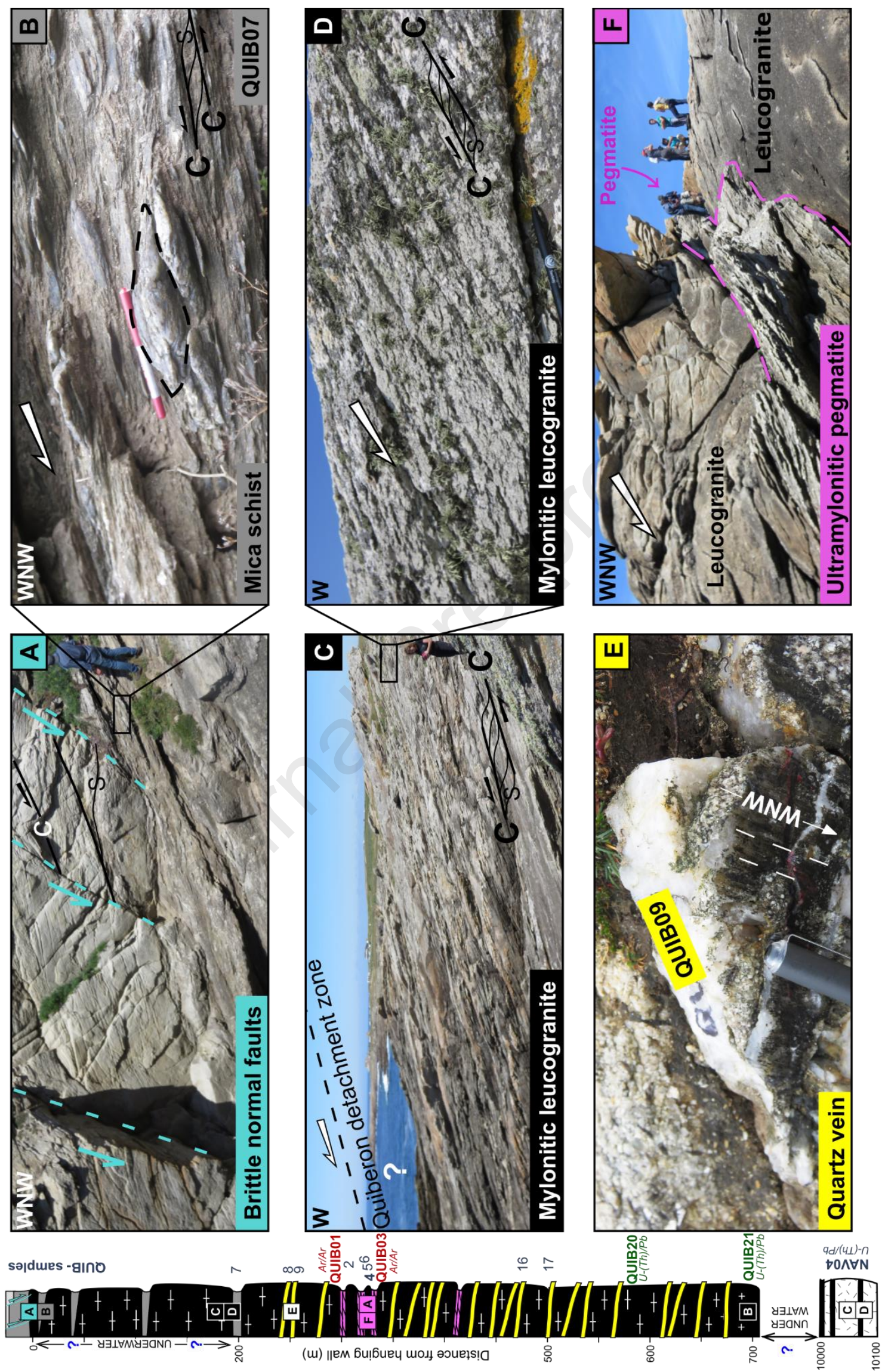
<smiles>C1=CC=C1</smiles>

Figure 2. Lithologic section in the Quiberon detachment footwall and associated field pictures; (A) Brittle normal faults in micaschist, (B) Sigmoidal quartz in micaschist (sample QUIB07), (C) Syntectonic leucogranite emplaced in the footwall of the Quiberon detachment zone, (D) Mylonitic leucogranite with C-S structures highlighting a top-to-the-WNW sense of shear, (E) West-dipping quartz vein with WNW-ESE trending lineation supported by tourmaline; $(\mathrm{F})$ High-strain zone made of ultramylonitic pegmatite (see text for explanation and Table 10 of the supplementary material for GPS coordinates).

Figure 3. Lithologic section in the Quiberon detachment footwall and associated field pictures; (A) Ultramylonitic pegmatite (QUIB04, 05, 06) intruding coarser-grained mylonitic leucogranite (QUIB01, 02, 03), (B) Magmatic foliation in weakly deformed leucogranite, (C) and (D) Folded paleosome/mesosome and leucosome layers characterizing the migmatites at Port-Navalo (see text for explanation and Table 10 of the supplementary material for GPS coordinates).
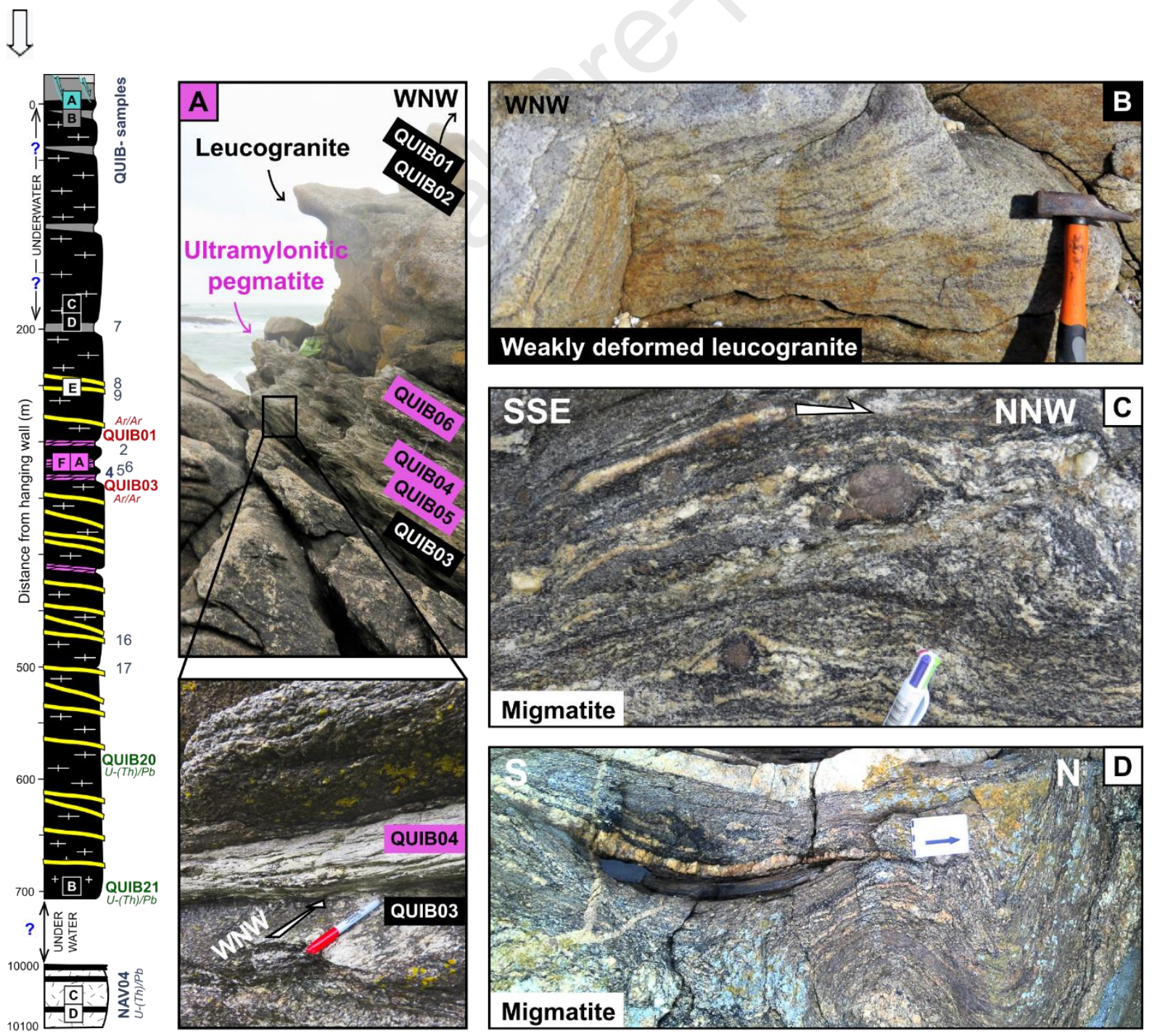
Figure 4. Microstructures from the Quiberon detachment footwall. Sections are cut perpendicular to foliation and parallel to lineation. Ms: muscovite; Qz: quartz; Fp: felspar; To: Tourmaline. (A-E) Mylonitic leucogranite (QUIB01); (B) C-S structures; (C) Lenticular muscovite fish (group 1 of ten Grotenhuis et al., 2003); (D) Group 2 mica fish that form C-S structures indicating a top-to-the-WNW sense of shear; (E) muscovite fish in equilibrium with tourmaline form shear planes in mylonitic leucogranite; (F) Sub-solidus deformation microstructures such as rectangular and castellate quartz grain boundaries suggest that grain boundary migration (regime 3, Hirth \& Tullis, 1992) was the dominant dynamic recrystallization process; (G-I) Mylonitic leucogranite (QUIB03); (H) Group 1 micafish; (I) castellated quartz grain boundary. See text for explanation and Table 10 of the supplementary material for GPS coordinates. 

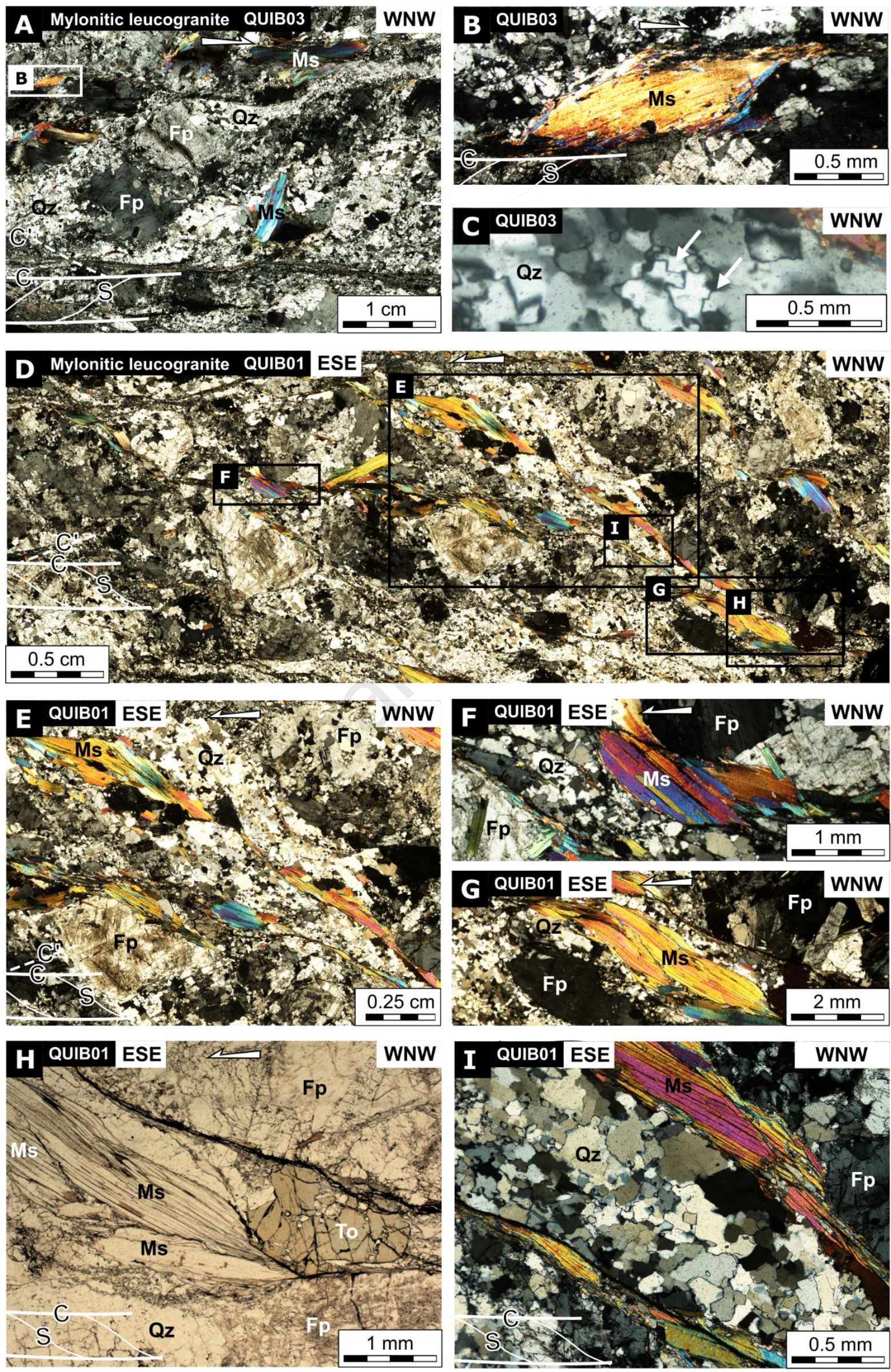

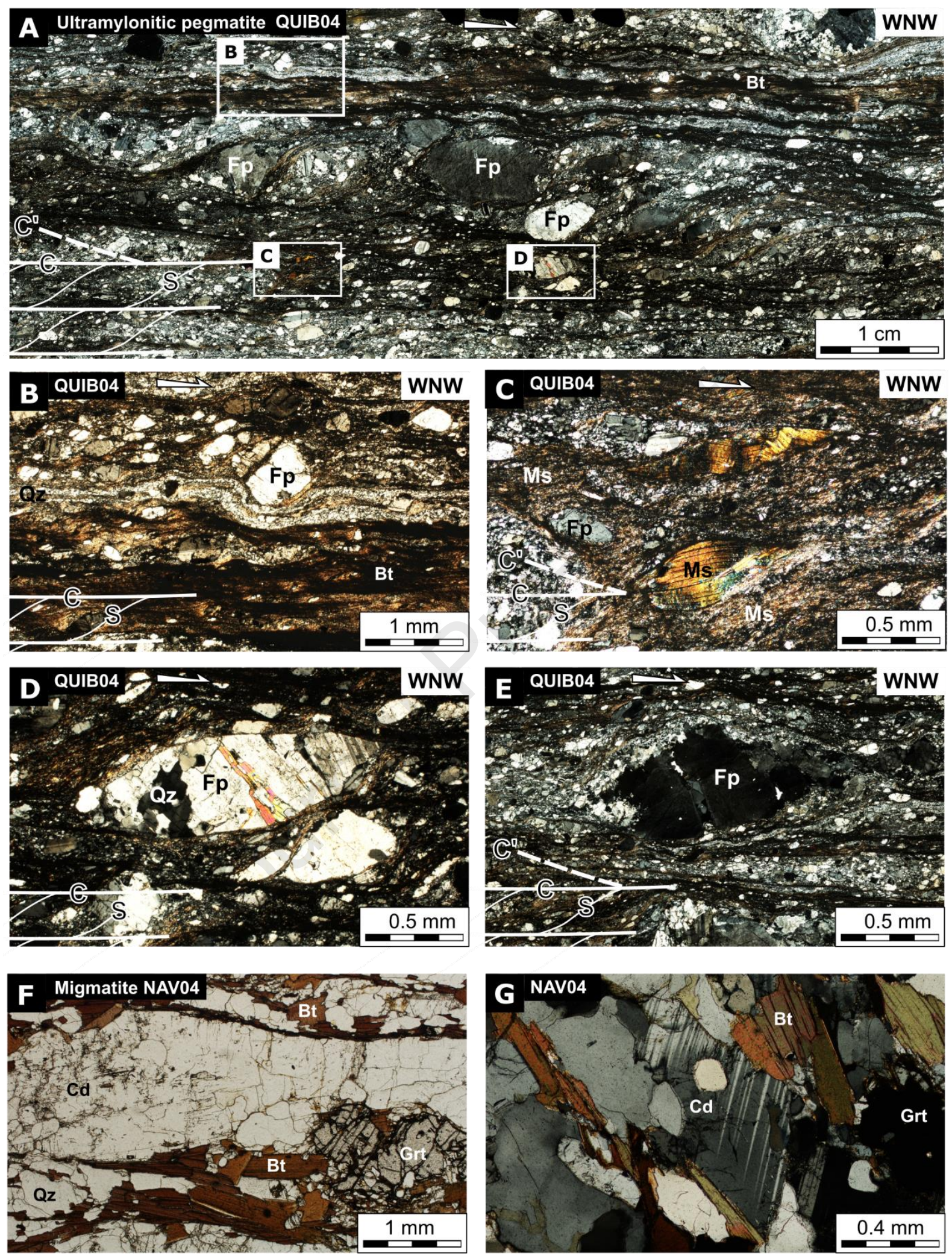

Figure 5. Microstructures from the Quiberon detachment footwall. Sections are cut perpendicular to foliation and parallel to lineation. Ms: muscovite; Qz: quartz; Fp: feldspar; Bt: biotite; Cd: cordierite; Grt: garnet. (A-C) Ultramylonitic pegmatite (QUIB04); (D-E) Garnetcordierite-bearing migmatite from Port Navalo (NAV04). See text for explanation and Table 10 of the supplementary material for GPS coordinates. 


\section{Timing and duration of meteoric water infiltration in the Quiberon detachment zone (Armorican Massif, Variscan belt, France)}

Camille Dusséaux ${ }^{1 *}$, Aude Gébelin ${ }^{1}$, Philippe Boulvais ${ }^{2}$, Gilles Ruffet ${ }^{2}$, Marc Poujol ${ }^{2}$, Nathan Cogné $^{2}$, Yannick Branquet ${ }^{2,3}$, Catherine Mottram ${ }^{4}$, Fabrice Barou ${ }^{5}$, Andreas Mulch ${ }^{6,7}$

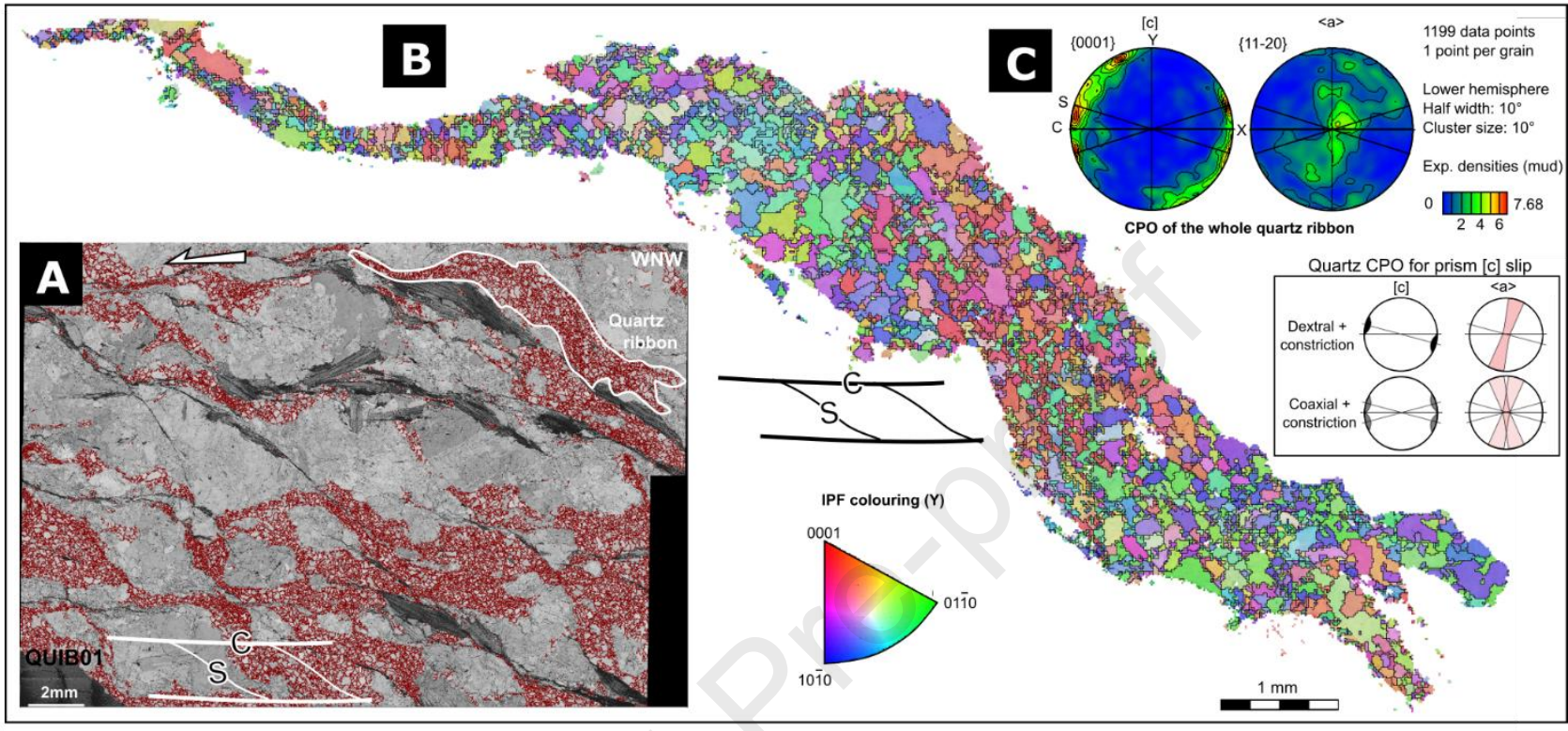

Figure 6. Microstructure and Crystallographic Preferred Orientation (CPO) of quartz grains from the QUIB01 mylonitic leucogranite sample measured using EBSD. Equal-area projection, Lower hemisphere. Foliation (XY plane) is vertical, and lineation (X) is horizontal in this plane. (A) Band contrast map with quartz grain boundary highlighted in red, (B) Map of a quartz ribbon quartz grain boundary with Inverse Pole Figure (IPF) coloring (Y represents the lineation direction) and (C) corresponding CPO. Framed quartz CPO for prism <c> slip come from Barth et al. [2010]. 


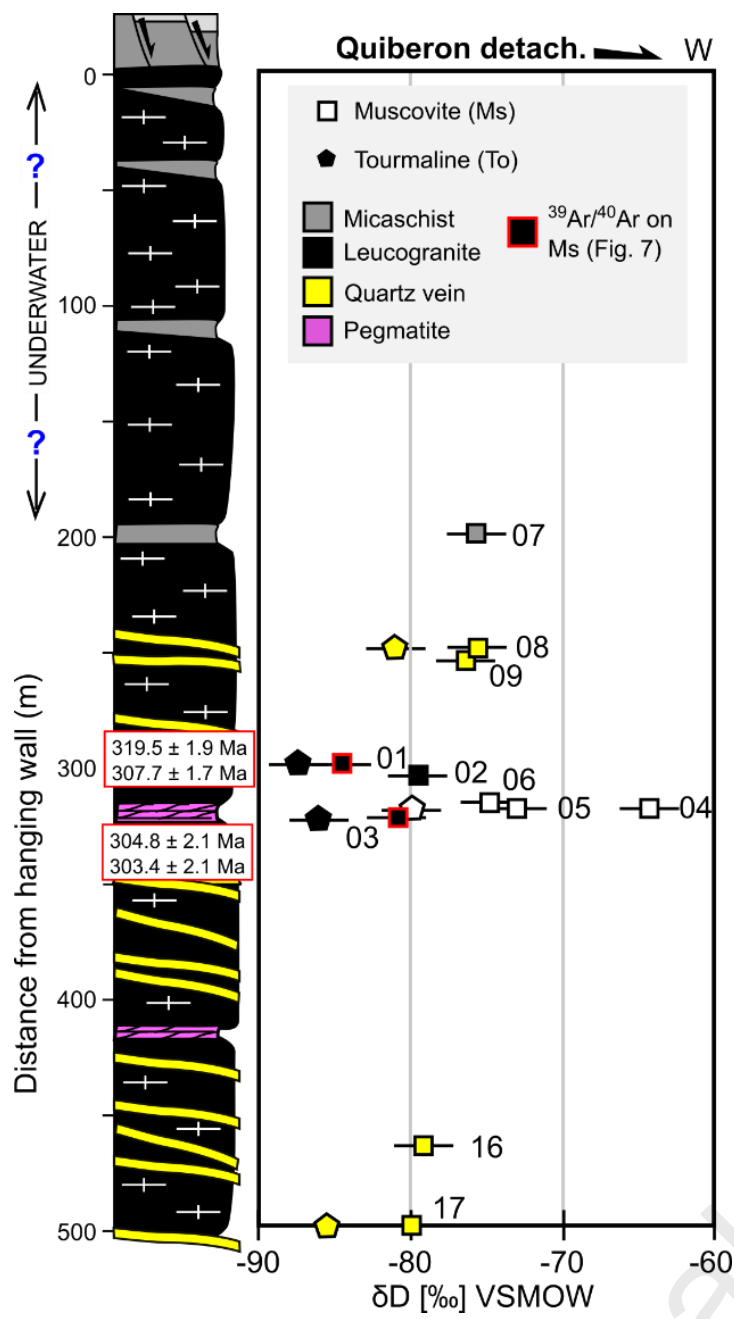

Figure 7. Hydrogen isotope analysis $(\delta \mathrm{D}[\%] \mathrm{VSMOW} \pm 2 \%$ ) of hydrous silicates (muscovite and tourmaline) from micaschist, leucogranite, quartz veins and pegmatite located in the footwall of the Quiberon detachment zone with respect to the distance from the hanging wall ( 200 to $500 \mathrm{~m}$ ).

Table 1. GPS locations, hydrogen isotope composition $(\delta \mathrm{D})$ of muscovite $(\mathrm{Ms})$ and tourmaline (To) from leucogranite, micaschist, quartz vein and pegmatite found in the mylonitic footwall of Quiberon detachment zone. $\delta \mathrm{D}_{\text {Water }}$ values have been calculated by using the hydrogen isotope muscovite-water and tourmaline-water fractionation factors $(\alpha)$ of Suzuoki and Epstein [1976] and Kotzer et al. [1993], respectively, and using temperatures indicated by the Ti-in-Ms thermometer $\left(546\right.$ and $569 \pm 42^{\circ} \mathrm{C}$ for QUIB03 and QUIB01 respectively, and the average temperature of $558 \pm 42^{\circ} \mathrm{C}$ for the other samples). Calculated $\delta \mathrm{D}_{\text {water }}$ values have propagated uncertainties of $\pm 5.2 \%$, considering the precision of isotopic analyses $\left(\delta \mathrm{D}_{\text {hydrous silicate }} \pm 2 \%\right.$ ) and the uncertainties linked to the temperature of recrystallization $\left(\mathrm{T} \pm 42^{\circ} \mathrm{C}\right.$ results in $\delta \mathrm{D}_{\text {Water }}$ uncertainties of $\pm 5 \%$ ). Structural distances of samples below the estimated detachment interface are indicated in $\mathrm{m}$ (see text for explanation). 


\begin{tabular}{|c|c|c|c|c|c|c|c|c|c|c|c|c|c|c|c|}
\hline \multirow[t]{2}{*}{ Name } & \multirow[t]{2}{*}{ Rock type } & \multirow{2}{*}{ 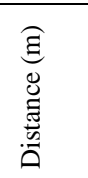 } & \multirow{2}{*}{$\begin{array}{c}\delta \mathrm{D}_{\text {Muscovite }} \\
(\% \mathrm{o}) \pm 2 \% \mathrm{o} \\
250 \mu \mathrm{m}<\mathrm{f}\end{array}$} & \multirow{2}{*}{$\begin{array}{l}\delta \mathrm{D}_{\text {Tourmaline }} \\
(\% \mathrm{o}) \pm 2 \% \mathrm{o} \\
250 \mu \mathrm{m}<\mathrm{f}\end{array}$} & \multirow{2}{*}{$\begin{array}{c}\delta \mathrm{D}_{\mathrm{Ms}} \\
- \\
\delta \mathrm{D}_{\mathrm{To}} \\
(\% 0\end{array}$} & \multirow{2}{*}{$\begin{array}{l}\text { Temperature } \\
\left({ }^{\circ} \mathrm{C}\right) \text { based } \\
\text { on Ti-in-Ms } \\
\text { thermometry }\end{array}$} & \multirow{2}{*}{$\stackrel{ \pm}{\stackrel{ \pm}{\left({ }^{\circ} \mathrm{C}\right)}}$} & \multicolumn{3}{|c|}{$\begin{array}{c}\delta \mathrm{D}_{\text {Water }}(\%) \text { based on the } \delta \mathrm{D}_{\text {Muscovite }} \\
\text { values and the Ti-in-Ms } \\
\text { thermometry }\end{array}$} & \multicolumn{3}{|c|}{$\begin{array}{l}\delta \mathrm{D}_{\text {Water }}(\%) \text { based on the } \delta \mathrm{D}_{\text {Tourmaline }} \\
\text { values and the Ti-in-Ms thermometry }\end{array}$} & \multicolumn{2}{|c|}{ Location } \\
\hline & & & & & & & & $\delta \mathrm{D}_{\text {Water }}(\%)$ & - & + & $\delta \mathrm{D}_{\text {Water }}(\%)$ & - & + & Latitude (DD) & Longitude (DD) \\
\hline $\begin{array}{c}\text { QUIB } \\
07\end{array}$ & Micaschist & 200 & -76 & & & 558 & 42 & -63 & -3 & 4 & & & & $47^{\circ} 30^{\prime} 21.85^{\prime \prime} \mathrm{N}$ & $03^{\circ} 09^{\prime} 00.54^{\prime \prime} \mathrm{W}$ \\
\hline $\begin{array}{l}\text { QUIB } \\
08\end{array}$ & Quarz vein & 250 & -76 & -81 & 5 & 558 & 42 & -63 & -3 & 4 & -70 & -4 & 4 & $47^{\circ} 30^{\prime} 26.2^{\prime \prime} \mathrm{N}$ & $03^{\circ} 08^{\prime} 58.6^{\prime \prime} \mathrm{W}$ \\
\hline $\begin{array}{l}\text { QUIB } \\
09\end{array}$ & Quarz vein & 255 & -76 & & & 558 & 42 & -63 & -3 & 4 & & & & $47^{\circ} 30^{\prime} 26.1 " \mathrm{~N}$ & $03^{\circ} 08^{\prime} 58.6^{\prime \prime} \mathrm{W}$ \\
\hline $\begin{array}{c}\text { QUIB } \\
01\end{array}$ & $\begin{array}{l}\text { Mylonitic } \\
\text { leucogranite }\end{array}$ & 300 & -85 & -87 & 2 & 569 & 42 & -73 & -2 & 4 & -77 & -3 & 5 & $47^{\circ} 29^{\prime} 0.85^{\prime \prime} \mathrm{N}$ & $3^{\circ} 8^{\prime} 42.68 " \mathrm{~W}$ \\
\hline $\begin{array}{l}\text { QUIB } \\
02\end{array}$ & $\begin{array}{l}\text { Mylonitic } \\
\text { leucogranite }\end{array}$ & 305 & -79 & & & 558 & 42 & -66 & -3 & 4 & & & & $47^{\circ} 29^{\prime} 0.85^{\prime \prime} \mathrm{N}$ & $3^{\circ} 8^{\prime} 42.68 " \mathrm{~W}$ \\
\hline $\begin{array}{l}\text { QUIB } \\
06\end{array}$ & $\begin{array}{l}\text { Ultramylonitic } \\
\text { pegmatite }\end{array}$ & 320 & -75 & & & 558 & 42 & -62 & -3 & 4 & & & & $47^{\circ} 29^{\prime} 0.85^{\prime \prime} \mathrm{N}$ & $3^{\circ} 8^{\prime} 42.68 " \mathrm{~W}$ \\
\hline $\begin{array}{l}\text { QUIB } \\
04\end{array}$ & $\begin{array}{l}\text { Ultramylonitic } \\
\text { pegmatite }\end{array}$ & 321 & -64 & & & 558 & 42 & -51 & -3 & 4 & & & & $47^{\circ} 29^{\prime} 0.85^{\prime \prime} \mathrm{N}$ & $3^{\circ} 8^{\prime} 42.68 " \mathrm{~W}$ \\
\hline $\begin{array}{l}\text { QUIB } \\
05\end{array}$ & $\begin{array}{l}\text { Ultramylonitic } \\
\text { pegmatite }\end{array}$ & 321.5 & -73 & -80 & 7 & 558 & 42 & -60 & -3 & 4 & -69 & -4 & 4 & $47^{\circ} 29^{\prime} 0.85^{\prime \prime} \mathrm{N}$ & $3^{\circ} 8^{\prime} 42.68 " \mathrm{~W}$ \\
\hline $\begin{array}{l}\text { QUIB } \\
03\end{array}$ & $\begin{array}{c}\text { Mylonitic } \\
\text { leucogranite }\end{array}$ & 322 & -82 & -86 & 4 & 546 & 41 & -68 & -4 & 3 & -74 & -5 & 3 & $47^{\circ} 29^{\prime} 0.85^{\prime \prime} \mathrm{N}$ & $3^{\circ} 8^{\prime} 42.68 " \mathrm{~W}$ \\
\hline $\begin{array}{l}\text { QUIB } \\
16\end{array}$ & Quarz vein & 465 & -79 & & & 558 & 42 & -66 & -3 & 4 & & & & $47^{\circ} 28^{\prime} 54.5^{\prime \prime} \mathrm{N}$ & $03^{\circ} 08^{\prime} 11.0^{\prime \prime} \mathrm{W}$ \\
\hline $\begin{array}{l}\text { QUIB } \\
17\end{array}$ & Quarz vein & 500 & -80 & -85 & 5 & 558 & 42 & -67 & -3 & 4 & -74 & -4 & 4 & $47^{\circ} 28^{\prime} 54.3^{\prime \prime} \mathrm{N}$ & $03^{\circ} 08^{\prime} 07.8^{\prime \prime} \mathrm{W}$ \\
\hline
\end{tabular}

\begin{tabular}{|c|c|c|c|}
\hline Propagated uncertainties & Error & Error (\%) & Propagated error in $\delta \mathrm{D}_{\text {Water }}$ \\
\hline Isotopic analysis $(\delta \mathrm{D})$ & $\pm 2 \% 0$ & $\pm 2 \% 0$ & $\pm 5.2 \% 0$ \\
\cline { 1 - 2 } Temperature deduced from Ti-in-Ms geothermometry & $\pm 42^{\circ} \mathrm{C}$ & $\pm 5 \% 0$ & \\
\hline
\end{tabular}



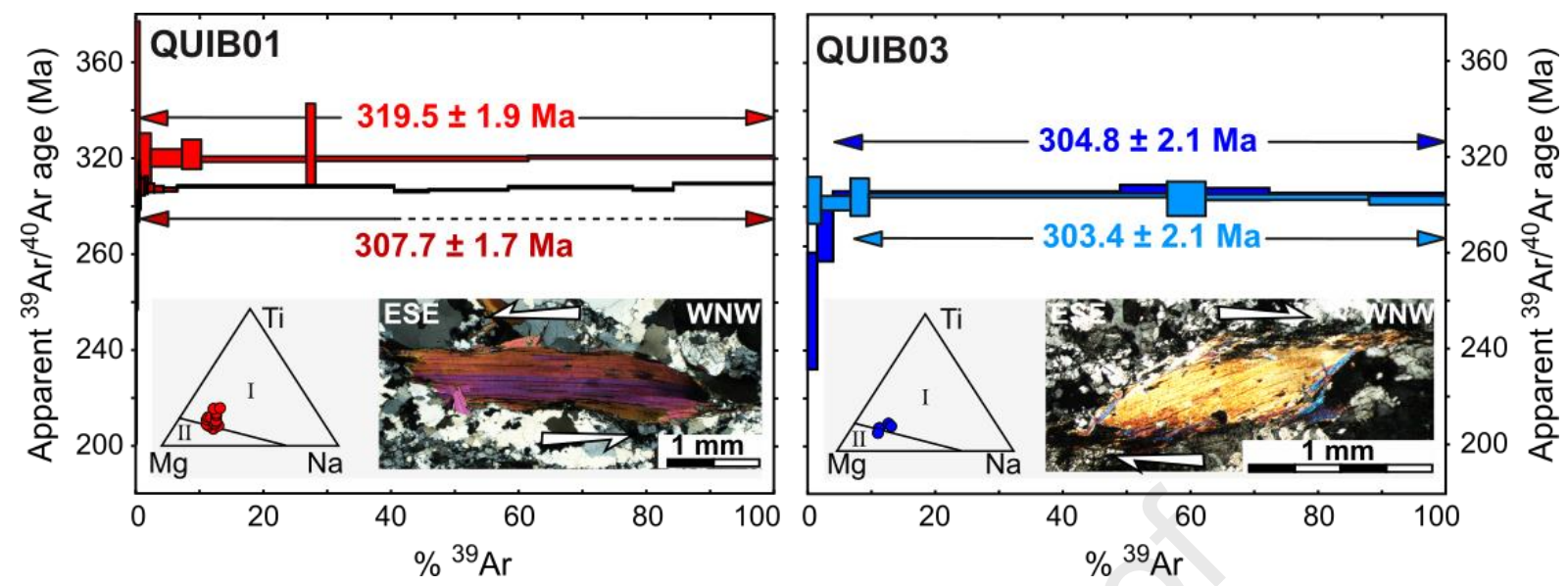

Figure 8. ${ }^{40} \mathrm{Ar} /{ }^{39} \mathrm{Ar}$ step-heating spectra of muscovite from mylonitic leucogranite samples QUIB01 and QUIB03, with associated ternary $\mathrm{Mg}-\mathrm{Ti}-\mathrm{Na}$ diagram for each analyzed muscovite grain that allow to decipher between (I) the primary and (II) the secondary muscovite fields (Miller et al., 1981) and aspect of muscovite fish (see text). Note that micafish of QUIB01 show clear grain boundaries whereas QUIB03 micafish display secondary recrystallization of small mica grains on rims. Apparent age errors are plotted at the $1 \sigma$ level and calculated ages are indicated at $2 \sigma$.

Figure 9. Monazite, zircon and apatite $\mathrm{U}-\mathrm{Th} / \mathrm{Pb}$ dating of weakly deformed (QUIB21) and mylonitic (QUIB20) Quiberon leucogranite samples. Results from the weakly deformed leucogranite sample: (A) ${ }^{206} \mathrm{~Pb} /{ }^{238} \mathrm{U}$ versus ${ }^{208} \mathrm{~Pb} /{ }^{232} \mathrm{Th}$ concordia diagram for monazite; (B) ${ }^{238} \mathrm{U} /{ }^{206} \mathrm{~Pb}$ versus ${ }^{207} \mathrm{~Pb} /{ }^{206} \mathrm{~Pb}$ diagram with free- and anchored- isochron dates and weighted mean of the ${ }^{207} \mathrm{~Pb}$ corrected dates obtained on apatite (unforced age in red and forced age in black); (C) apatite REE spectra. Results from the mylonitic leucogranite: (D) Tera-Wasserburg diagram for zircon; (E) ${ }^{238} \mathrm{U} /{ }^{206} \mathrm{~Pb}$ versus ${ }^{207} \mathrm{~Pb} /{ }^{206} \mathrm{~Pb}$ diagram with free- and anchored-isochron dates and weighted mean of the ${ }^{207} \mathrm{~Pb}$ corrected dates obtained on apatite; (F) apatite REE spectra. Note that apatite REE spectra is homogeneous in the weakly deformed sample (QUIB20) compared to the variable REE spectra in the mylonitic leucogranite sample (QUIB21). S\&K: Stacey and Kramers [1975] lead evolution model. 
Weakly deformed granite QUIB21
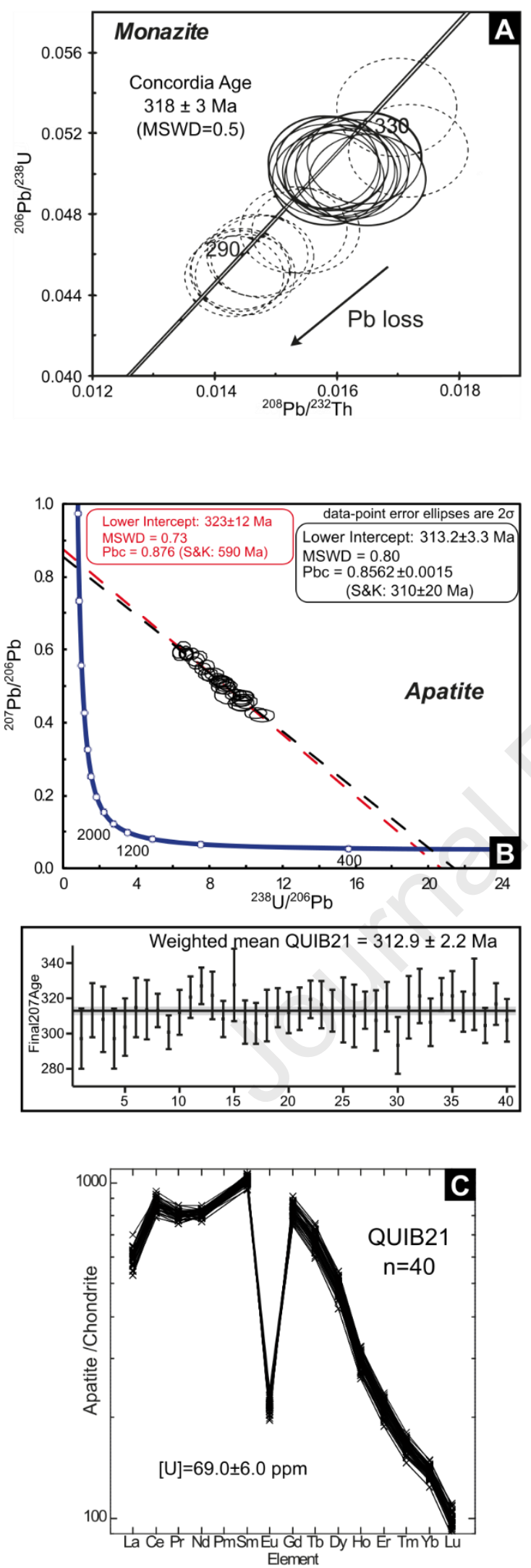

Deformed granite QUIB20
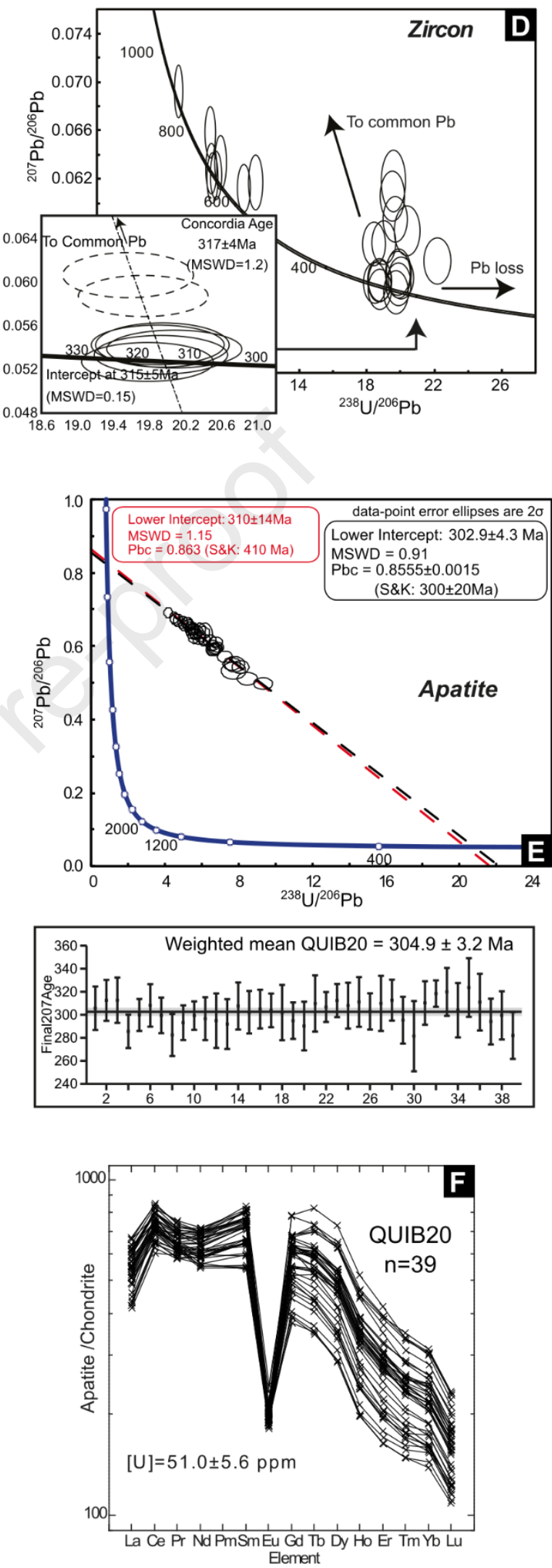

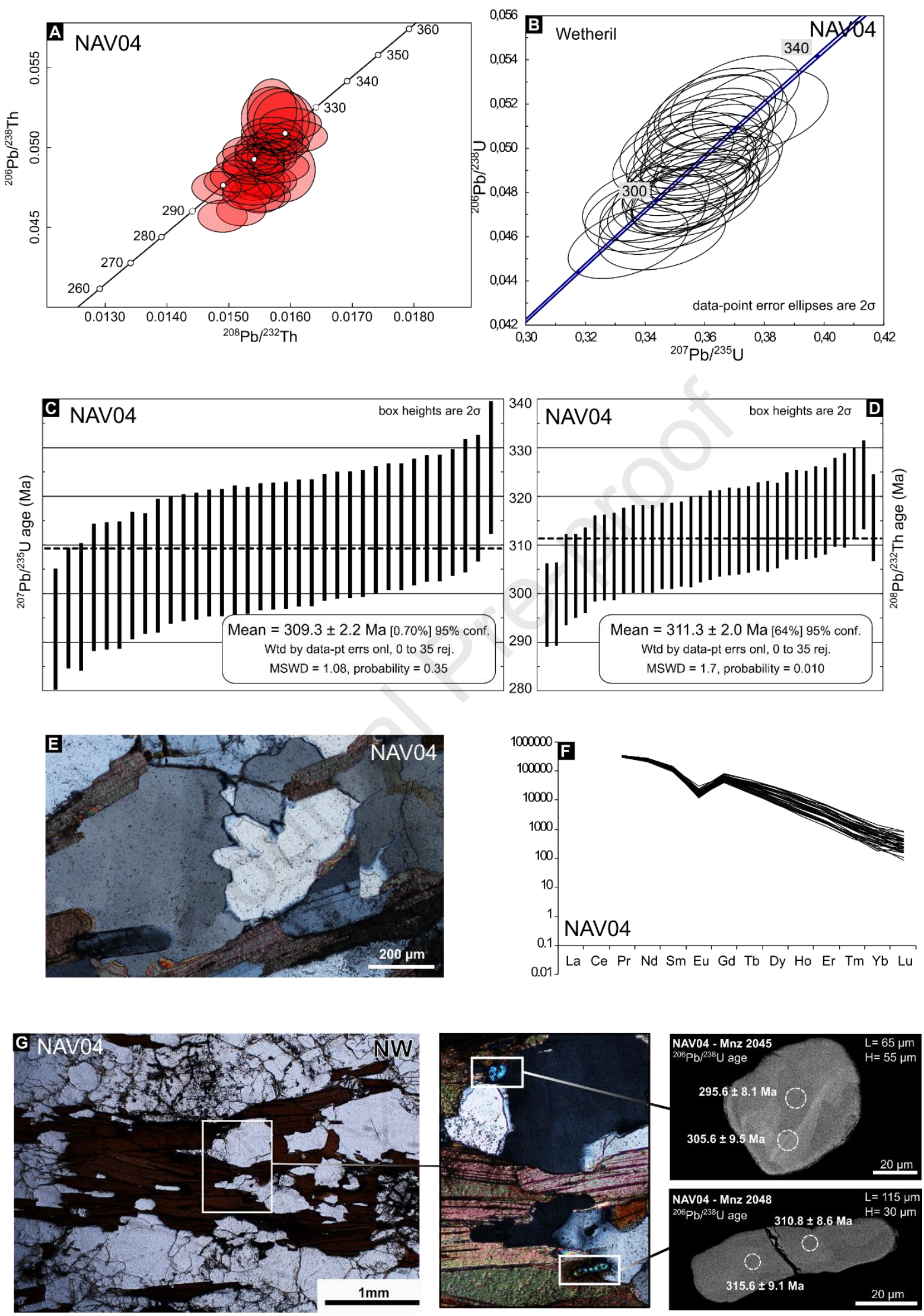
Figure 10. Monazite $\mathrm{U}-\mathrm{Th} / \mathrm{Pb}$ ages obtained on Port-Navalo migmatite (sample NAV04) located in the footwall of the Quiberon detachment zone. (A) ${ }^{206} \mathrm{~Pb} /{ }^{238} \mathrm{U}$ vs ${ }^{208} \mathrm{~Pb} /{ }^{238} \mathrm{Th}$ diagram; (B) Wetheril diagram; (C) Weighted average of the ${ }^{207} \mathrm{~Pb} /{ }^{235} \mathrm{U}$ ages; (D) Weighted average of the ${ }^{208} \mathrm{~Pb} /{ }^{232} \mathrm{Th}$ ages; (E) Quartz grain boundary migration; $(\mathrm{F})$ Monazite REE spectrum highlighting a magmatic signature; $(\mathrm{G})$ Microstructural aspect of monazite grains and associated ${ }^{206} \mathrm{~Pb} /{ }^{286} \mathrm{U}$ spot ages.

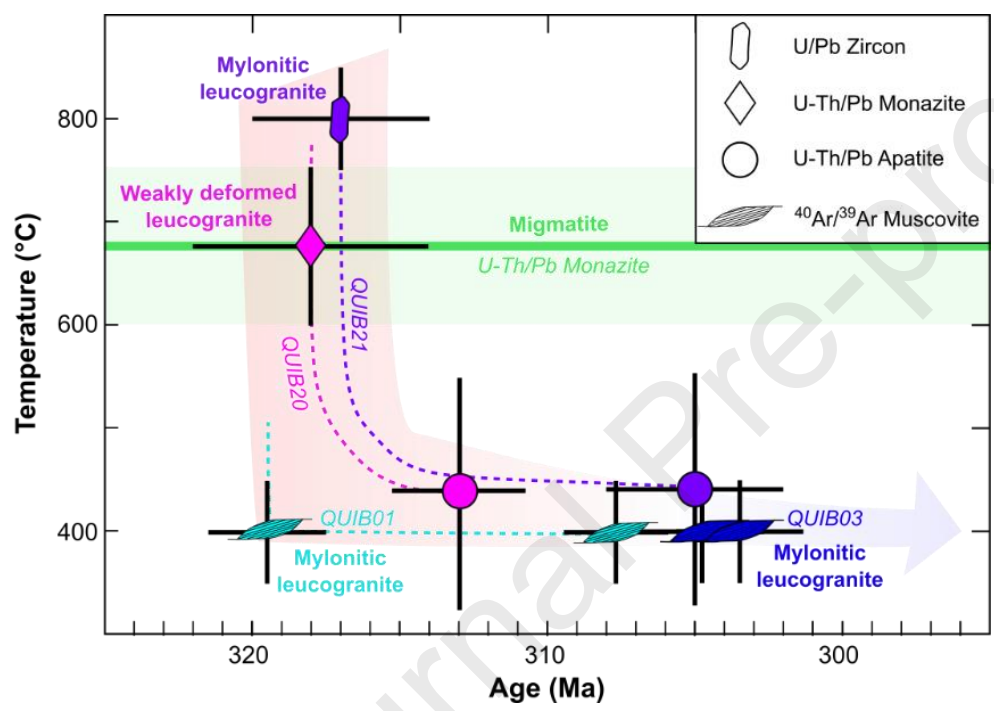

Figure 11. Temperature $\left({ }^{\circ} \mathrm{C}\right)$ versus time $(\mathrm{Ma})$ plot summarizing the geochronology results obtained for weakly deformed to mylonitic leucogranite in the Quiberon footwall. 
3 Camille Dusséaux ${ }^{1,2^{*}}$, Aude Gébelin ${ }^{1,3}$, Philippe Boulvais ${ }^{4}$, Gilles Ruffet ${ }^{4}$, Marc Poujol ${ }^{4}$,

4 Nathan Cogné ${ }^{4}$, Yannick Branquet ${ }^{4,5}$, Catherine Mottram ${ }^{6}$, Fabrice Barou ${ }^{7}$, Andreas

5 Mulch $^{8,9}$

$6 \quad{ }^{1}$ SoGEES, University of Plymouth, PL48AA Plymouth, UK

7 2Université Grenoble Alpes, ISTerre, F-38058 Grenoble, France

$8 \quad{ }^{3}$ CEREGE, Aix-en-Provence, France

$9 \quad{ }^{4}$ Univ Rennes, CNRS, Géosciences Rennes - UMR 6118, F-35000 Rennes, France

$10 \quad{ }^{5}$ ISTO, Université d'Orléans, CNRS, BRGM, France

$11{ }^{6}$ SEGG, University of Portsmouth, PO1 3QL Portsmouth, UK

$12{ }^{7}$ Géosciences Montpellier, CNRS, Université de Montpellier, Université des Antilles, France

$13{ }^{8}$ Senckenberg Biodiversity and Climate Research Centre (SBiK-F), Frankfurt, Germany

$14{ }^{9}$ Institute of Geosciences, Goethe University Frankfurt, 60438 Frankfurt, Germany

15 *Corresponding author: Camille Dusséaux (ca.dusseaux@gmail.com)

16 Highlights

- $\delta \mathrm{D}$ values of synkinematic hydrous minerals document the presence of 300 Ma-old meteoric fluids in a key Variscan detachment zone.

- Meteoric fluid-rock interactions occurred during high-temperature deformation $\left(>500^{\circ} \mathrm{C}\right)$ in the Quiberon detachment footwall.

- Coeval detachment activity, leucogranite emplacement and migmatization allowed the hydrothermal system to be maintained for $\sim 17 \mathrm{Myr}$. 


\section{Declaration of interests}

$\bigotimes$ The authors declare that they have no known competing financial interests or personal relationships that could have appeared to influence the work reported in this paper.

$\square$ The authors declare the following financial interests/personal relationships which may be considered as potential competing interests:

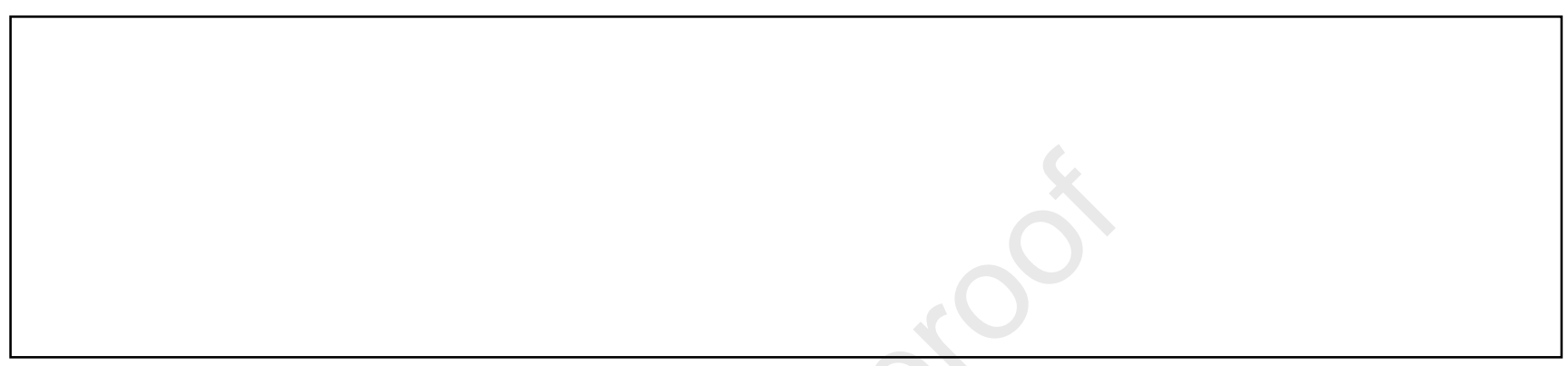

